\title{
İşyerinde Psikolojik Yıldırma Olgusunun Çalışan Verimliliği Üzerine Etkisi: MOSB'de Bir Saha Araştırması
}

\author{
Duygu SEÇKIN HALAÇ*
}

Cansu GÜLOĞLU**

\begin{abstract}
$\ddot{O} Z$
Bu çalışma, psikolojik yıldırma (mobbing) olgusunu incelemeyi ve psikolojik yıldırma davranışlarının çalışan verimliliği üzerindeki olası etkilerini incelemeyi amaçlamaktadır. Bu doğrultuda Manisa Organize Sanayi Bölgesi'nde (MOSB) imalat yapan KOBİlerde yönetici pozisyonlarında bulunmayan idari personel üzerinde bir saha araştırması gerçekleştirilmiş olup, ele alınan çalışma grubu için psikolojik saldırı bileşenlerinden ilişkiye ve yapılan işe saldırılara maruz kalan personelin verimliliğinin beklenenin aksine arttı̆̆ yönünde bulgulara ulaşılmıştır.
\end{abstract}

Anahtar Kelimeler: Psikolojik yıldırma, mobbing, çalışan verimliliği, verimlilik karşıtı davranışlar

JEL sinıflandirmast: $M 10$, M12

\section{The Effects Of Mobbing On Employee Productivity: A Field Study In Manisa Organized Industrial Zone}

\begin{abstract}
ABSRACT
The aim of this study is to reveal the possible effects of mobbing on employee productivity. With this aim, a field study consisting of administrative staff of SMEs in Manisa Organized Industrial Zone, who are not holding any managerial duties, was conducted and unexpectedly, attacks to relations and jobs dimensions of mobbing showed significant and positive relations with employee productivity.
\end{abstract}

Key words: mobbing, employee productivity, counterproductive work behaviors

JEL classifications: $M 10$, M12

\section{GíRiş}

Yönetim organizasyon literatüründe işyeri şiddeti kavramı kullanıldığ1 zaman verimlilik karşıtı davranışların öncülü olarak uygulanan fiziksel ve psikolojik saldırılar birlikte akla gelmektedir. Fiziksel şiddetten öte, psikolojik şiddetin uzun dönemde birikimli etkilerinin hem çalışan hem de örgüt açısından daha ciddi sorunlara yol açacağı ortadadır (Vickers, 2010). Uluslararası Çalışma Ofisi (ILO) işyeri şiddetini tanımlanırken çalışanların bir başka çalışan tarafından direk ya da dolaylı olarak güvenlik, sağlık ya da iş ile ilgili konularda hedef alındığ 1 ve bunun sonucunda yaralandığı, zarar gördüğg̈, incindiği ya da aşağılandığı her tür davranış ve hareketi dâhil etmektedir (ILO, 2002). Verimlilik karşıtı davranışlar, şirket içi hırsızlıklar, sabotajlar, çalışanlar arası sözlü ve fiziksel şiddet, alkol ve madde bağımlılığı, cinsel taciz, disiplin problemleri, iş kazaları ve daha fazlasını

\footnotetext{
*Dr., Ege Üniversitesi, Kadın Çalışmaları Ana Bilim Dalı, duyguseckinhalac@ gmail.com

** Yaşar Üniversitesi, SBE, İşletme Yüksek Lisans Mezunu, cansuguloglu @ gmail.com
} 
içeren geniş bir spektrumda tartış1lırken (Ones, 2002); örgüte ve/veya çalışan(lar)a kasıtlı olarak zarar vermek amacı ile örgüt içinde cereyan eden şiddet içerikli davranışlar ve hareketler olarak tanımlanmaktadır (Spector \& Fox, 2005). Düşük iş performansı, işe devamsızlık, işten ayrılma ve işyeri kazalarına dayalı çalışan verimliliğinde düşüşler gibi olumsuz sonuçlar, örgüte yönelik verimlilik karşıtı davranışların en sık karşılaşılan yansımalarından birkaçı olarak görülmektedir (Jex \& Britt, 2008).

Çalışma yaşamı çok eski tarihlere kadar uzansa da işyerinde psikolojik yıldırma ya da diğer adı ile mobbing kavramı 1980'lerde ortaya çıkan görece yeni bir kavramdır. 19.yyda biyologlar tarafından hayvan davranışlarını açıklarken kullanılmaya başlayan mobbing kavramı, psikolog Leymann tarafından 1980'lerde ilk kez işyerinde özellikle hedef alınan bir çalışana bir ya da daha çok çalışan tarafindan uygulanan yıldırmaya yönelik psikolojik saldırıyı tanımlamak için kullanılmıştır (Leymann, 1990). Leymann (1990, 1996) mobbing kavramını, sistematik bir biçimde (haftada en az 1 kez olmak üzere en az 6 ay boyunca), bir ya da bir grup çalışan tarafından hedefe alınmış bir kişiye uygulanan, onu çaresiz ve savunmamız bir durumu sokma amacı taşıyan, düşmanca ve etik dışı bir davranış olarak tanımlamaktadır.

Avrupa Yaşam ve Çalışma Koşullarının İyileştirilmesi Vakfi'nın 2000 yılındaki raporuna göre Avrupa'da işyerinde psikolojik yıldırma vakalarına en çok rastlanan ülkeler Finlandiya (\%15), Hollanda (\%14) ve Birleşik Krallık (\%14) olarak belirtilmiş olup, Avrupa' da çalışanların \%8'i yani yaklaşık olarak 12 milyon çalışan psikolojik yıldırma mağdurudur (Paoli \& Merllie, 2001, s.28). Almanya'da yapılan bir araştırmaya göre 1,5 milyon çalışan işyerinde psikolojik yıldırmaya maruz kalmakta olup, Alman Federal Çalışma Bakanlığı verilerine göre intiharların yüzde 10'u işyerinde maruz kaldığı psikolojik yıldırma nedeniyle gerçekleşmektedir (Çalışma ve Sosyal Güvenlik Bakanlığı, 2014). Leymann (1990) İsveç'te meydana gelen intihar olaylarının her y11 \%10 ila \%15'inin (100-300 arasi) işyerinde psikolojik yıldırma nedeni ile yaşadığı psikosomatik duruma bağlı olduğunu belirtmektedir. Almanya'da yapılan bir araştırma psikolojik yıldırma mağdurlarının \%98,7'sinin sağlık problemleri ya da iş yerinde farklı sorunlar yaşadığını ortaya koymaktadır (Sloan vd., 2010).

Leymann (1996), İsveç'te çalışan nüfusun \%25'inin erken emeklik kararlarının işyerinde psikolojik yıldırma kaynaklı olduğunu belirtmektedir. Birleşik Krallık'da 2007 yılında psikolojik yıldırma sebebi ile 33,5 milyon gün kaybı, yaklaşı 200.000 kişinin işyerini terk etmesi ve 100 milyon güne eşdeğer bir verimlilik kaybı tahmini üzerinden hesaplanan maliyetin 13,75 milyar Sterlin olduğu düşünülmektedir (ILO 2016, s. 15). Uluslararası Çalışma Örgütü’nün (ILO) 2000 yılının Ekim ayında yayımladığı rapora göre, Almanya' da her yıl psikolojik sağlık problemleri nedeniyle alınan izinler 2,2 milyon Avro maliyete neden olmaktadır. İşyerinde psikolojik yıldırma, ekonomik bakımdan yaklaşık olarak 13 milyar Avroluk zarara sebebiyet vermektedir. Birleşik Krallık Sağlık ve Güvenlik Bakanlığı'nın yayınladığı bir rapora göre psikolojik yıldırma gibi işyeri 
sorunlarının neden olduğu iş stresinin ülke ekonomisine yıllık maliyeti yaklaşık 4 milyar Sterlindir (Çalışma ve Sosyal Güvenlik Bakanlığı, 2014).

Psikolojik yıldırmanın işyerlerinde karşılaşılan etik dışı bir davranış olmasının ötesinde mağdur çalışanlar için bir insan hakları ihlali meselesi olduğu unutulmamalıdır (Carbo \& Hughes, 2010). Ancak diğer taraftan psikolojik yıldırma, bu tip eylemlere rastlanan örgütler açısından da oldukça yüksek maliyetler oluşturmaktadır. Sağlık harcamalarındaki artışlar, dava masrafları, düşen ürün kalitesi, yüksek çalışan devir hızı, artan devamsızlıklar, zayıf müşteri ilişkileri, sabotajlar, işe bağlılıkta azalma, düşük yaratıcılık, işe zaman ayırmak yerine sohbete ve başka şeylere vakit ayırma gibi direk ve dolaylı maliyetlerden söz edilmektedir (Gardner \& Johnson, 2001). 1998 yılında 775 kişi üzerinde yapılan bir araştırmaya göre, katılımcıların \%53'ünün uğradıkları psikolojik yıldırma sebebi ile çalışma zamanlarında kayıp yaşadığı, \%37'sinin örgütsel bağl11ı̆̆ında azalma olduğu, \%28'inin saldırganı yok sayma çabası için çalışma zamanından kayıplar yaşadığı, \%22'sinin işyerinde sarf ettikleri çabada düşüşler olduğu ve $\% 12$ 'sinin işyerini değiştirdiği psikolojik yıldırma davranışlarının direk etkileri olarak sunulmuştur (Gardner \& Johnson, 2001). Bir diğer çalışmanın bulguları psikolojik yıldırma mağdurlarının, işyerinde normal performanslarının sadece \%85'ini gösterebildiklerini belirtmektedir (Carbo \& Hughes, 2010). Hoel vd. (1999) yönetsel görevi olmayan sıradan bir personelin işten ayrılmasının şirkete maliyetinin 2.000 ila 13.000 Dolar olduğunu belirtmektedir.

Toplumsal, örgütsel ve bireysel seviyedeki yıkıcı sonuçlarından daha da vahim olan durum, psikolojik yıldırma mağdurlarının psikolojik bir saldırıya maruz kaldıklarını, bir şeylerin yanlış olduğunu dahi fark edemiyor olmalıdır. Bu sebeple mağdurların bir kısmı uzun süreler boyunca maruz kaldığı davranışa karşı hiçbir eylemde bulunmamaktadırlar ki, bu durum bireylerin fiziksel rahatsızlıklarını ve ruhsal yaralarını derinleştirirken iş performanslarında da düşüşler olmasına ve verimliliklerinin azalmasına yol açmaktadır (Divincova \& Sivakova 2014). Dolayısıyla, psikolojik yıldırma davranışlarının çalışan verimliliği üzerine etkisinin araştırılması hem örgütsel hem de ülke ekonomisine olan katkıları nedeni ile toplumsal düzeyde önem arz etmektedir. Bu çalışmada da Manisa Organize Sanayi Bölgesi'nde imalat yapan KOBI'lerde yönetici pozisyonlarında bulunmayan idari personel üzerinde bir saha araştırması gerçekleştirilerek işyerinde psikolojik yıldırma boyutları ve çalışan verimliliği ilişkisi tartışılacaktır.

\section{I.PSIKKOLOJIK YILDIRMA (MOBBING)}

Latince "kararsız kalabalı" anlamına gelen "mobile vulgus" sözcüklerinden türeyen "mob" sözcüğü, İngilizce kanun dış1 şiddet uygulayan düzensiz kalabalık veya "çete" anlamına gelmektedir. "Mob" kökünün İngilizce eylem biçim olan "mobbing" ise; psikolojik şiddet, kuşatma, taciz, rahatsız etme veya sıkıntı verme anlamına gelmektedir (Tınaz, 2011, s. 7). Bir uzlaşıya varılamamakla beraber, Türkiye'de yapılan araştırmalara bakıldığında mobbing kavramının işyerinde psikolojik taciz/terör, işyerinde moral/manevi taciz, işyerinde zorbalık, duygusal şiddet, yıldırma ya da işyerinde psikolojik yıldırma gibi Türkçe karşılıklar seçilerek kullanıldığı görülmektedir (Tınaz, 2011, s.17). Bu çalışmada, 
İngilizce bir terim olan "mobbing" için, kavram karmaşası yaratmamak adına "psikolojik yıldırma" terimi kullanılacaktır. Her işyerinde karşılaşılabilecek olan psikolojik yıldırma davranışları, mağdur ile aynı hiyerarşik seviyede ya da üstü pozisyonundaki kişi(ler)den gelebileceği gibi, nadir olarak rastlanmakla beraber astı pozisyonundaki diğer çalışanlar tarafından da gelebilir (Zapf vd., 1996, Minibaş-Poussard vd., 2018). Belirli bir sıklıkta (en az haftada bir) ve uzun bir süre boyunca (en az altı ay) devam eden psikolojik yıldırma davranışları, sıklığı ve uzun sürmesi sebebiyle mağdurlarda ciddi zihinsel, psikosomatik ve sosyal tükenmişliğe yol açabilmektedir (Leymann, www.leymann.se, Erişim Tarihi 11.08.2016). Literatürde yapılan mobbing tanımlarına bakıldığında (i) tacize maruz kalan bir kurban/mağdur, (ii) bu kurbanın iş performansı ve tutumlarında meydana gelen bariz değişiklikler ve (iii) uygulanan psikolojik saldırının belli bir sistematikte bilinçli olarak yapılıyor olması gibi birkaç temel noktada uzlaşıya varıldığı görülmektedir (Rayner \& Hoel,1997).

Psikolojik yıldırmanın nedenleri konusunda çeşitli fikir ayrılıkları bulunmaktadır. Aslında yıldırmanın nedenlerini ayrıntılı biçimde ortaya koyan yeterli araştırma da bulunmamaktadır. Çünkü bu nedenleri ortaya koyacak tek bir yöntem bulunmadığı gibi, bu konuda yapılan araştırmalar genelde görüşmeler sonucu elde edilen nitel bilgilere dayanmaktadır. Dolayısıyla, psikolojik yıldırmayı tek bir nedene bağlamak doğru değildir. Çünkü yıldırma birden fazla nedenin aynı anda etkileşime geçmesi ile ortaya çıkabilmektedir (Gökçe, 2008, s.39). İşyerlerinde psikolojik yıldırmanın ortaya çıkma nedenleri üzerine yapılan çeşitli araştırmalarda psikolojik yıldırmanın saldırganın psikolojik yapısından, psikolojik yıldırmaya uğrayan kişinin psikolojisinden ve örgütten kaynaklanan nedenler olmak üzere üçe ayrılmıştır.

Leymann, saldırganın psikolojik yapısından kaynaklanan nedenleri birisini bir grup kuralını kabul etmeye zorlamak, düşmanlık beslemekten haz almak, can sıkıntısı içerisinde zevk arayışı ve önyargılarını sağlamlaştırmak gibi dört temel nedene bağlamaktadır (Davenport vd., 2003, s.58). Örgütlerde en sık görülen saldırgan tipleri (i) narsist, (ii) hiddetli/bağırgan, (iii) ikiyüzlü, (iv) megaloman, (v) eleştirici ve (vi) hayal kırıklığına uğramış olanlar olarak belirtilmektedir (Tınaz, 2011, s.69-88).

Leymann ve Gustafsson (1996) psikolojik yıldırma davranışlarının mağdurun özelliklerine dayandırılmasına karşıdır ve herkesin psikolojik yıldırma kurbanı olabileceği görüşündedir. Ancak farklı çalışmalara bakıldığında, bazı özelliklere sahip kişilerin işyerinde psikolojik yıldırma kurbanı olma tehlikesiyle daha çok karşı karşıya olduklarına dair görüşler bulunmaktadır. Huber (1994) bu anlamda dört kişilik özelliğine vurgu yapmaktadır: (i) yalnız bir kişi (örneğin erkeklerin yoğun olduğu bir ofiste çalışan tek bir kadın veya kadınların çok sayıda olduğu bir işyerinde çalışan tek bir erkek), (ii) acayip bir kişi (örneğin engelli, farklı etnik gruba dahil ya da asosyal bir kişi gibi), (iii) başarılı bir kişi (örneğin önemli bir başarı göstermiş, amirinin veya doğrudan yönetimin takdirini kazanmış ya da müşterinin övgüsünü almış bir kişi, kolayca çalışma arkadaşları tarafından kıskanılabilir), (iv) yeni gelen bir kişi (örneğin daha önce o pozisyonda çalışan 
kişinin çok seviliyor olması ya da yeni gelenin, orada çalışanlardan daha fazla bir takım özelliklerinin bulunması gibi).

Örgütlerde psikolojik yıldırmanın ortaya çıkmasına neden olabilecek birçok faktör olabilir. Leymann (1996) örgüte bağlı iki temel neden üzerinde durmaktadır. Bunlardan bir tanesi yetersiz anlaşmazlık yönetimi ve kötü iletişimdir (bir yöneticinin bu tarz psikolojik saldırıları görmezden gelmesi ya da çalışanlar arasında taraf olması gibi). İkincisi ise örgüt kültürü ve örgütsel prosedürlerdeki uygulama hatalarıdır (farkına varılan psikolojik yıldırma davranışlarının cezasız bırakılması ya da örgüt kültürünün yeni gelenlere karşı yersiz şakalar ve alayları içerir sosyalleşme davranışları barındırması gibi). Diğer taraftan, sektörel rekabet artışı, firma içinde çalışanlar arasında stresi ve rekabet artışını da beraberinde getirmektedir. Bireysel çıkarların öne geçtiği, zayıf iletişimin olduğu belirsizlik zamanları psikolojik yıldırmaların da ortaya çıkmasına sebep olabilmektedir (Vartia,1996). Benzer şekilde, büyük ve hiyerarşik yapılar, ayrılan düşük insan kaynakları bütçeleri, uygulanan kapalı kapı politikaları, şirket içi zayıf iletişim kanallarının varlığı, çalışanlarca yönetime yapılan şikâyetlerin ciddiye alınmaması, yetersiz liderlik özelliklerinin sergilenmesi ve yönetimsel hatalar da psikolojik yıldırmaya sebep olan örgütsel nedenler arasında sayılmaktadır (Tınaz, 2011 s.123124; Çalışkan \& Tepeci, 2008; Yücetürk, 2003; Zapf \& Einarsen, 2001).

Ekonomik kriz dönemlerinde firmalar küçülme politikaları uygulamaktadırlar. Böyle dönemlerde kişiyi, kendi rızası ile işten ayrılmaya zorlamak için planlı bir yıldırma hareketi başlatılabilmektedir. Bu süreç, örgüt stratejisinin bir parçası olarak uygulanabilmektedir. Örgütler bu konuda yasal sınırları zorlayıp acımasız tavırlar sergileyebilmektedirler (Çobanoğlu, 2005, s.72). Dolayısıyla psikolojik yıldırma bilinçsizce gerçekleştirilen bir örgütsel strateji olarak da kullanılarak, istenmeyen bir çalışanın şirketten uzaklaştırılması ya da çalışan sayısının azaltılma yöntemi olarak da uygulanabilmektedir (Yücetürk, 2003). İşyerinde en uç noktada karşıllaşllabilecek olumsuz sosyal etkileşim (Vartia,1996) olarak düşünülen psikolojik yıldırmanın nihai hedefinin, bu yıldırmalar sonucunda mağduru işyerinden ayrılmaya itmek olduğu belirtilmektedir (Davenport vd. 2003).

İş yaşamında psikolojik yıldırma olaylarının görülme sıklığı, toplumun sosyal, ekonomik, kültürel ve ahlaki norm ve değerleri ile yakından ilgilidir. Bölgeler arası göç, yabancılaşma, özgüven yetersizliği, hemşerilik ağı etkileşimi işyerinde psikolojik yıldırmayı besleyen bir zemin oluşturmaktadır. İşyerinde psikolojik yıldırmaya zemin oluşturan toplumsal norm ve değerler başında güçlü olanın zayıf olanı yok etme algısı, ortak duyarlılık alanları ve ortak çalışma kültürünün yok sayılması, değişim ve yeniliklerin çalışanların aleyhine kullanılması gelmektedir (Atman, 2012, s.165).

Psikolojik yıldırma sadece hedef alınan bireye uygulansa da etkileri ülke ekonomisini etkileyecek kadar geniş çapta olabilmektedir. Genel olarak bakıldığında psikolojik yıldırma davranışlarının bu davranışlara maruz kalan kurban, örgüt ve toplum üzerinde olmak üzere üç temel seviyede ciddi etkileri olduğu görülmektedir. Uzun süre sistematik olarak maruz bırakıldıkları düşmanca 
tavırlar kurbanlar üzerinde psikolojik, psikosomatik ve sosyal olarak güçlük yaşamalarına sebep olmaktadır (Leymann \& Gustafsson, 1996). İşyerinde psikolojik yıldırma sürecinde en büyük zararı gören elbette mağdur bireydir (Tetik, 2010, s.86). Psikolojik yıldırma sürecinin ilk aşamasında genellikle her tür durum karşısında bireyde nedensiz ağlama, uyku bozuklukları, hemen sinirlenme ve konsantrasyon güçlügü gibi etkiler ortaya çıkmaktadır. İkinci aşamada ilk aşamadaki etkilere yüksek tansiyon, mide şikayetleri, depresyon, işyerine gitmek istememe, işe geç kalma gibi belirtiler de eklenmektedir. Üçüncü aşamada ise depresyonun şiddeti artmakta, panik atak ve endişe durumu ortaya çıkmaktadır. Kazalar ve intihara yönelme, daha çok psikolojik yıldırma sürecinin son aşamasında görülmektedir (Yücetürk, 2003; Atman, 2012, s.167). Sistematik tekrarlanan psikolojik yıldırma süreci kişinin kendine olan öz saygısının azalmasına da sebep olabilmektedir (Vartia, 2001). Ayrıca süreç bireyi ilk olarak ruhsal açıdan etkilemekte, daha sonra fiziksel etkiler eklenmekte ve son aşamaya ilerledikçe sosyal ve ekonomik açıdan etkilemektedir. İleri dönemlerde ise kurbanın kişisel ve mesleki hayatına verilen bu hasarlar, sosyal izolasyona, ciddi sağlık harcamalarına, işsiz kalmasını takiben de olası gelir kayıplarına yol açabilmekte, böylece kurban sosyal ve ekonomik olarak da zarar görmeye başlayabilmektedir (Tınaz, 2006; Tınaz, 2011 s.158).

Psikolojik yıldırma olgusunun, birey üzerinde olduğu kadar örgüt üzerinde de tahrip edici etkileri olmaktadır. İşveren açısından ortaya çıkan hasarlar öncelikle ekonomik niteliktedir. Ancak bunun yanında ağır sosyal etkilerin oluşması da kaçınılmazdır (Tınaz, 2011, s.161). Bir örgüt psikolojik yıldırma davranışlarını görmezden gelme ya da buna karşı önlem almama yolunu seçerse örgüt kültürü de ciddi şekilde zarar görecektir. Örgüt içinde güvenin azalması, çalışan motivasyon/performanslarında düşüş gibi verimlilik karşıtı davranışların görülmesi kaçınılmaz olacaktır. Ayrıca, işe geç kalma, gelmeme, rapor alımlarında artış, çalışanların işten ayrılmalarını takiben yeni alım süreçleri ve onların sosyalleşme süreçleri gibi süreçleri de düşünürsek ek maliyetlere de yol açabilmektedir. Dahası, genel performans düşüklüğüne bağlı olarak üretimsel ve operasyonel harcamalarda artış, örgüt itibarında azalma ve olası dava giderlerinde artış gibi başka ek maliyetler de eklenebilecektir (Leymann, 1996; Yücetürk, 2003; Tinaz, 2006; Bozbel \& Palaz, 2007).

Toplum seviyesinde incelendiğinde ise toplum içinde mutsuz bireylerin sayısının artmasıyla olaylara karşı kayıtsızlık, işsizlik ve intihar eğilimi de artmakta ve böylece aile ve toplum içindeki huzur bozulmaktadır. Diğer taraftan vergilerden ödenen sağlık masrafları, vergi kayıpları, sosyal yardım kuruluşlarına talebin artması, zihinsel sağlık sorunlarındaki artış ve malulen emeklilik istekleri toplumu önemli düzeyde etkileyebilmektedir (Leymann, 1996; Tınaz, 2006; Çobanoğlu, 2005, s.99).

Dolayısıyla, farklı seviyelerde ciddi olumsuz sonuçlar doğurabilen psikolojik yıldırma sürecinin anlaşılabilmesi için öncelikle işyerinde görülen ve psikolojik yıldırmanın habercisi olan davranışların belirlenmesi gerekmektedir. Psikolojik yıldırma süresince görülen davranışlar, tek tek ele alındığında, bazıları 
tamamen negatif olarak görülebilmesine ve bazen de kabul edilemez olarak algılanmasına rağmen; bazıları sadece normal etkileşim davranışları olarak değerlendirilebilmektedir. Hatta bu davranışlar, bir kez için hoş görülebilir ya da saldırganın "kötü gününde" olduğu varsayılarak anlayışla karşılanabilmektedir. Ancak davranışlar, sistematik olarak uzun bir süre içinde tekrarlanırsa anlamları değişmekte, tehlikeli bir silaha dönüşerek örnek bir psikolojik yıldırma olayının ortaya çıkışını tetiklemekte ve kasıtlı bir tacize dönüşmektedir (Tınaz, 2011, s.53). Leymann saldırgan(lar)1n kurban(lar)a yönelttiği 45 davranış gözlemlemiş olup, bunları beş kategoride sınıflandırmaktadır: (i) iletişime yönelik saldırılar, (ii) sosyal ilişkilere yönelik saldırılar, (iii) sosyal konuma saldırılar, (iv) mesleki/profesyonel yaşamın niteliğine saldırılar ve (v) sağlığa yönelik saldırılar.

İletişime yönelik saldırılardan bahsedildiğinde, kurbanın kendini ifade etme fırsatının amirleri, meslektaşları ya da çalışma arkadaşları tarafından engellenmesi, sözünün devamlı kesilmesi, kurbanın azarlanması ve/veya kendisine karşı yüksek sesle bağırılıyor olması, kurbanın özel yaşantısının sürekli eleştiriliyor olması, kendisine sözlü ya da yazılı tehditlerde bulunuluyor olması, ya da bir takım organizasyon/etkinliklere davet edilmemesi gibi tavırlara rastlanabilmektedir.

Sosyal ilişkilere saldırılardan bahsedilirken, kurban ile çalışma arkadaşları veya meslektaşlarının konuşmasının da yasaklanabildiği şekilde bilinçli olarak iletişimin kesilmesi, kurbanın çalışma arkadaşlarından uzakta bir ofiste çalıştırılması hatta görmezden gelinmesi ya da konuşmaya çalıştığı durumlarda sözünün sürekli kesilerek konuşmasının engellenmesi gibi durumlardan bahsedilmektedir.

Sosyal konuma saldırılar, kurbanın arkasından konuşulması, hakkında çeşitli yerli yersiz dedikoduların yayılması, kurbanın herhangi bir kusurunun/ yürüyüşünün/ konuşmasının/ özel yaşamına ilişkin konuların ya da milliyetinin alay konusu yapılması, kendisinin gülünç duruma düşürülmesi, akıl hastası olduğuna dair kuşkular yaratılması, kendisinin psikolojik destek alması gerektiğine dair imalarda bulunulması, politik ve dini inançlarına saldırılması, kurbanın öz saygısını zedeleyecek bir iş yapmaya zorlanması, yaptığ iş̧e ilişkin aldığı kararların sürekli sorgulanması ve başarısının haksız yere eleştirilmesi şeklinde gerçekleşebilmektedir.

Mesleki ve özel yaşamın niteliğine yönelik saldırılar, kurbana yetkinliklerinin altında iş verilmesi ya da hiç iş verilmemeye başlanması, verilen görevlerin geri alınması, kendisinin yeteneksiz olduğuna inandırılması için kapasitesinin çok üstünde ya da uzmanlık alanın dışında işler verilmesi şeklinde görülebilmektedir.

Sağlığa yönelik saldırılardan bahsedildiğinde de kurbanın fiziksel olarak ağır işler yapmaya zorlanması, gözünü korkutmak için itiş-kakış gibi hafif şiddet uygulanması, kurbana sözlü, fiziksel ya da cinsel tacizde bulunulması gibi durumlardan söz edilmektedir.

Yapılan davranışların psikolojik yıldırma davranışı olarak değerlendirmesi için yukarıda ifade edilen beş grup maddenin hepsi aynı anda uygulanmak zorunda değildir. Psikolojik yıldırmayı uygulayan kişinin/kişilerin esas amacı, hedef seçtiği 
kişi/kişilerin duygusal ve/veya fiziksel olarak sağlığını derinden etkileyip onu/ onları saf dışı bırakmaktır. Literatürde psikolojik yıldırma ölçümlerinin nasıl yapıldığına bakıldığında temelde iki yöntem öne çıkmaktadır. Bunlardan birincisi öz bildirim ölçekleri olarak belirtilmiş olan psikolojik yıldırma kavramının ne olduğunun katılımcılara anlatıldığı ve kendilerinin bu tarz davranışlara maruz kalıp kalmadıklarının sorulduğu yöntemdir. Diğeri ise operasyonel yöntem olarak adlandırılmış olan, bir dizi davranış listesinin katılımcılara sunulduğu ve belirtilen her bir davranışa maruz kalıp kalmadıkları, şayet kaldılar ise ne sıklıkla ve ne süreyle maruz kaldıkları gibi soruları katılımcıların yanıtladığı yöntemdir (Carbo \& Hughes, 2010). Operasyonel yöntem anket yöntemi ile yapılan saha çalışmalarında sıklıkla tercih edilirken, ölçümünde zaman içerisinde çeşitli versiyonları literatürde yer alsa da en çok atıf alan iki temel ölçeğe rastlanmaktadır. Bunlardan biri 1990 y1lında psikolojik yıldırma ölçümü için ilk ölçeği oluşturan Leymann'ın Leymann Psikolojik Terör Envanteridir (Leymann Inventory of Psychological Terror- LIPT). Diğeri ise 1997'de Einarsen ve Raknes tarafindan geliştirilmiş olan Olumsuz Davranışlar Ölçeğidir (Negative Acts QuestionnaireNAQ).

Akademik çalışmalarda çeşitli yöntemlerle psikolojik yıldırma davranışlarının varlığı araştırılırken, mağdurların hak arayışlarına karşı ilk yasal düzenleme 1993 yılında İsveç’te ve takiben 2001 yılında Fransa'da olmak üzere Almanya, İsviçre ve İtalya gibi Avrupa ülkelerinde görülmeye başlanmıştır. Türkiye 2006 yılında Avrupa Konseyi Gözden Geçirilmiş Avrupa Sosyal Şartı bağlamında 'Onurlu Çalışma Hakkı' başlıklı maddede ismen belirtilmese de psikoloji yıldırmaya ilişkin hükümlere yer vermiştir (İzmir \& Fazlığlu, 2010, s. 30-31). 2006 y1lında Türkiye'de ilk kez psikolojik yıldırma tanımı ve olgusu hukuksal çerçevede tanınmış (Köse \& Uysal, 2010) olsa da mağdurları bu mağduriyetlerini yasal zemine taşıdıklarında olmazsa olmaz olarak belirtilen "kanıtlama" zorunluluğu (İzmir \& Fazlıoğlu, 2010, s. 34) ile karşı karşıya kalmaktadırlar. Fiziksel ve somut kanıtlardan çok psikolojik bir süreç olarak devam eden işyerindeki bu tarz yıldırmaların ölçümü ve kanıtlanması noktasında uygulamada ve hukuki düzlemde farklı çözüm önerileri ve yaklaşımlara ihtiyaç olduğu da konunun farklı bir boyutu olarak karşımıza çıkmaktadır.

\section{II.ÇALIŞAN VERIMLILLIĞí}

Verimlilik temel olarak bir işyerinde çıktıların girdilere oranı ile hesaplanan bir performans ölçütüdür. Örgütsel kayıtlarda verimlilik üç şekilde karşımıza çıkabilmektedir (Marks vd., 1986): (1) üretimde yüzdesel olarak harcanmış olan çalışma saati (sadece üretimde harcanan toplam saat / toplam çalışma saati), (2) etkinlik oranı (belirlenmiş kalite standartlarına uygun olarak üretilmiş olan ürün sayısı / endüstri mühendislerinin hesapladığı çıktı oranları), ve (3) toplam verimlilik (toplam kazanılan zaman [geçekleşen üretim miktarı/beklenen üretim miktarı] / toplam harcanan zaman. Diğer taraftan Yu ve Park (2006) çalışan verimliliğini (1) çalışan başına satış oranı: satışlar / toplam çalışan sayısı ile (2) çalışan başına katma değer: (katma değerin işletme karı ile aynı düşünüldüğü varsayılarak)katma değer/toplam çalışan sayısı + çalışan 
maliyeti + aşınma payı + kira + vergi ve diğer ödenekler ile hesaplamaktadır. Bu örneklerde olduğu gibi verimlilik ya da çalışan verimliliği genel olarak oransal teknik bir performans aracı olarak düşünülmektedir.

Özellikle üretim sektöründe olduğu gibi girdi-çıktı oranları ile verimlilik hesaplamaları yapılabilmekte ise de günümüzde hizmet sektörünün gelişimi ve üretim firmaları bile olsa bilişsel üretim yapan beyaz yaka çalışanların verimliliğini bu yöntemlerle hesaplamak kolay değildir (Koopman vd., 2002). Çalışan verimliliği, bir çalışanın fiziksel ve düşünsel gücünden en yüksek düzeyde faydalanmayı ve bu elde edilmiş olan yüksek çalışma temposunun sürekliliğinin sağlanmasını ifade etmektedir (Sabuncuoğlu, 2005). Dolayısıyla bu çalışmada çalışan verimliliği çalışanların kendi beyanları sonucu yapmaları gereken işleri yaparken işyeri kaynaklı dikkat dağıtıcı unsurların daha önce göstermekte oldukları performanslarına nasıl etki ettiği ile belirlenmeye çalışılmıştır.

Literatürde geniş bir yelpazede tartışılan verimlilik karşıtı davranışlar (Türkçe literatürde üretkenlik dışı davranışlar olarak da görülmektedir) temel olarak örgüt çıkarlarına zarar verecek şekilde örgüte ve/veya çalışanlarına yönelmiş tutum ve davranışların tümü şeklinde tanımlanırken verimlilik ve üretkenlik üzerine etkileri göz önünde tutulduğunda örgütsel normları ciddi şekilde zedeleyerek, işyerinin beklenen işleyişine ve çıktılarına zarar vermektedir (Berry vd., 2012; Boddy, 2014). Bu davranışlar işyerinde saldırgan tavırlar sergilemek ya da hırsızlık gibi açık eylemler şeklinde olabileceği gibi, bilinçli olarak işi yapılması gereken şekilde yapmamak ya da direktifleri izlememek pasif bir proteste şeklinde de görülebilmektedir (Fox vd.,2001).

İşyerindeki saldırganlık içeren davranışlar ve verimlilik ilişkisi üzerine yapılan bazı çalışmalarda (Fritscher-Porter, 2003; Gabriel, 1998; Hornstein, 2003; Johnson \& Indvik, 2001; McCune, 2000; Zauderer, 2002), hastalık/depresyon, işe gelmeme, azalan örgütsel bağlılık, işyerinde fiziksel olarak bulunmasına rağmen verimliliğinde azalma, diğer çalışanlara ve müşterilere karşı benzer kaba tavırları takınma, iletişiminde azalma ve ortaya çıkan sorunları üstlerine aktarmada/ raporlamada azalama gibi bulgular belirtilmektedir (Hutton \& Gates, 2008). Yapılan bir araştırmada, işyerinde psikolojik yıldırmaya maruz kalınmasına bağlı olarak aktif çalışma zamanlarında azalma/kalite düşüklüğü, iş değiştirme düşüncesinde artış, örgütsel bağl1lıkta azalma, çalışırken işi yapmak için gösterilen gayret/çabada azalma, işyerinde harcanan zamanda azalma ve son olarak da iş değiştirmelerin yaşandığı bulgularına rastlanmaktadır (Pearson vd., 2000). Benzer şekilde Hutton ve Gates (2008) çalışmalarında saldırgan hareketlerin verimlilik azaltıcı rolü yanında, örgüt ve sağlık sistemi için ne kadar maliyetli olduğuna dikkat çekmektedir. İşyerindeki şiddetin işyerlerine devamsızlık, işten ayrılma, yeni işe alımlar ve dava masrafları şeklinde finansal maliyetler olarak direk etkileri olduğu gibi, verimlilikte yaşanan düşüşler ile itibar, imaj ve rekabette yaratacağı dolaylı zararlardan da bahsedilmektedir. Ayrıca, mağdurların işten ayrılmalarının, işten ayrılanlar yerine yeni işe alımların yapılması ve eğitim masrafları da düşünüldüğünde, hastalık durumu ile işe gelmemeden daha maliyetli hale geldiği belirtilmektedir (Rayner vd., 2001). 
Çalışanların duygusal durumları ve ruh sağlıkları iş performansı belirleyenlerinden olarak kabul edildiğinden örgütler için önemlidir (Wright \& Cropanzano, 1997; Penny \& Spector, 2005). Yani duygusal ve ruhsal olarak sağl1klı olan bir çalışan verimli bir çalışan olarak adlandırılmaktadır (Wright ve Cropanzano, 2004). Sosyal mübadele teorisine göre (Emerson, 1976), çalışanlar kendilerine yöneltilmiş olan adil bulmadıkları tutum ve davranışlar karşısında olumsuz davranışlar sergileyerek cevap vermektedirler (Boddy, 2004). Çalışanların duygusal ve ruhsal sağlıklarının bozulmasında en önemli etkenler olarak psikolojik yıldırmada sıklıkla karşılaşılan işyerinde uygulanan kaba ve kötü muameleler (Lim \& Cortina, 2005), kendisine zarar verilmek üzere seçilmiş bir kurban olduğu algısı (Jockin vd., 2001) düşünülebilir. Devamsızlıklardaki artış iş performansı ve verimlilik üzerinde olumsuz etkiler yaratmakla beraber, psikolojik yıldırmaya maruz kalmış olan kurbanların sadece devamsızlık durumları verimlilik azaltıcı faktör olarak düşünülmemelidir. Bir çalışan fiziksel olarak işyerinde bulunduğu zamanlarda da verimliliğinde azalma ile karşılaşılabilir (Koopman vd., 2002). Dolayısıyla psikolojik yıldırma kurbanları, maruz kaldıkları tutum ve davranışlardan dolayı amirlerinin direktiflerine uymuyor, fiziksel olarak işyerinde görülseler de gün içinde yapması gereken işlerini erteleyip doğrudan işle ilgisi olmayan şeylerle uğraşıyor, işine odaklanamıyor, işlerini yapacak motivasyonu/enerjiyi kendinde bulamıyor, sergileyebileceğinin altında performans sergiliyor olabilmektedirler. Maruz kalınan davranışlara tepki olarak sergilenen tüm bu ve benzeri davranışlar nitekim bireysel sonuçları dışında örgütsel zararlara da yol açabilecektir.

\section{YÖNTEM, ANALIZ VE BULGULAR}

\section{A. Gerekçe ve Amaç}

1980’li yıllarda Kuzey Avrupa’da psikolojik yıldırma çalışmaları başlamış olup, 1990 ortalarında ilgi diğer Avrupa ülkelerine de yayılmıştır (Zapf \& Einarsen, 2001). Türkiye'de akademik literatürde psikolojik yıldırma kavramına olan ilginin başlaması ise 2000'li yılların başlarına rastlamaktadır. Türkiye'de yapılmış olan ampirik saha çalışmaları incelendiğinde, hizmet sektörü üzerine yapılan çalışmaların çokluğu dikkat çekerken, mevcut literatürdeki çalışmaların, çalışanların demografik özelliklerinin psikolojik yıldırma davranışlarına maruz kalma üzerinde etkili olup olmadığı, hangi davranışların yıldırmaya yönelik psikolojik saldırı davranışları olarak algılandığı, mağdurların gözünden neden psikolojik saldırıya uğradıklarını düşündükleri ve bu saldırıların hangi pozisyonda yer alanlar tarafından geldiğini ve bu psikolojik saldırılara maruz kalan çalışanların maruz kaldıkları bu davranışlara nasıl tepki verdikleri üzerinde durulduğu, buna ek olarak bazı çalışmalarda ise psikolojik saldırıların örgütsel bağlılık üzerine etkisini araştırmış oldukları görülmektedir (Çalışkan \& Tepeci, 2008; Seçkin-Halaç \& Bulut, 2010). Yapılan literatür taramalarının bulguları ışığında, psikolojik yıldırma mağdurlarının daha çok hizmet sektörü çalışanları olduğu açıkça belirtilmektedir (Köse \& Uysal, 2010). İlk ve orta öğretim yapan okullarda yapılan araştırmalarda öğretmenlerin, \%85 (Cemaloğlu \& Ertürk, 2007), \%41 (Gündüz \& Y1lmaz, 2008) ve \%65,9 (Doğan-Kılıç, 2009) gibi çok yüksek oranlarda psikolojik yıldırma 
algıladıklarını göstermektedir. Akademide bu oranlar \%15,8 (Tanoğlu, 2007), \%11,6 (Tigrel \& Kokalan, 2009), \%26 (Seçkin-Çelik \& Minibaş-Poussard, 2017) olarak tespit edilmiştir. Sağlık sektörü üzerine yapılmış araştırma bulgularında belirtilen örneğin \%86 (Yıldırım \& Yıldırım, 2007), \%29,8 (Ergun-Özler, 2008), $\% 78,7$ (Tengilimoğlu \& Akdemir-Mansur) ve \%62,2 (Durmuş vd., 2018) gibi yüksek psikolojik yıldırma oranları oldukça düşündürücüdür. KOBİ'ler özelinde psikolojik yıldırma çalışmaları Türkiye literatüründe sayılıdır. Kırklareli'nde hizmet sektöründeki KOBİ çalışanları üzerinde yapılan araştırma bulguları genelleştirilememekle beraber çalışanların \%35,5'inin psikolojik yıldırmaya maruz kalırken \%44,3'ünün geçmişte maruz kalmış olduğu (Keskin \& Canbaz, 2014), İkitelli Organize Sanayi Bölgesinde yapılan bir diğer çalışma ise \%56,2'sinin maruz kaldığı (Acar vd., 2017) yönünde bir eğilim sunmaktadır. Ayrıca, firmalarda idari işlerle ilgili birimlerde çalışanların hizmet sektörü çalışanları gibi üretim sektöründe çalışanlara oranla iş yerinde daha fazla psikolojik yıldırmaya uğramakta oldukları da literatürde belirtilmektedir (Vartia, 1996:204; Fettahlıoğlu 2008, s.67$68)$.

Türkiye'de yürütülmüş olan ampirik çalışmalardan çok azı psikolojik yıldırma ve verimlilik karşııtı davranışları - özelde de iş performansını- bir arada incelemiş olup (örneğin Turan, 2006; Demir \& Çavuş, 2009), ilgili çalışmalar psikolojik yıldırma eğilimlerindeki yüksek oranlar nedeni ile hizmet sektörünü ele almışlardır. $\mathrm{Bu}$ çalışma, ülkemizde işyerinde psikolojik yıldırma kavramının çalışan verimliliği ile ilişkisini istatistiksel olarak test eden sayılı çalışmalardan biri olarak bu ilişkiyi, daha önce tek başına araştırma konusu olmamış olan, üretim firmalarında çalışmakta olan idari personeli incelemesi açısından önemlidir. Diğer yandan, Türkiye İstatistik Kurumu'nun (TÜİK) Küçük ve Orta Büyüklükteki Girişim İstatistikleri 'ne (2016) göre, KOBİ'ler 2014 y1lında toplam girişim sayısının \%99,8'ini ve toplam istihdamın \%74,2'sini oluşturmuş olup, ülke ekonomisindeki önemleri ortadadır. Dolayısıyla, psikolojik yıldırma gibi iş yaşantısında yüksek oranlarda rastlanan ve bireysel yıkımları yanında örgütsel ve ülke ekonomisi açısından yıkıcı sonuçları ile KOBI'ler bağlamında ele almak da önem taşımaktadır.

Bu doğrultuda bu çalışmanın amacı, Manisa Organize Sanayi Bölgesi'nde (OSB) imalat yapan KOBİ'lerde yönetici pozisyonlarında bulunmayan idari personelin evreni oluşturduğu bir saha çalışmasında, işyerlerinde uygulanan yıldırmaya yönelik psikolojik saldırıların çalışan verimliliği ile ilişkisini araştırmayı amaçlamaktadır.

\section{B. Araștırmanın Hipotezleri ve Kapsamı}

$\mathrm{Bu}$ araştırmada çalışanların psikolojik yıldırmaya maruz kalmaları ile çalışan verimliliği arasındaki ilişsi araştırılmıştır. Çalışmada psikolojik yıldırma davranışı literatürde belirtildiği gibi beş ana kategoride ele alınmıştır. Bu bağlamda araştırmanın hipotezleri şu şekilde kurulmuştur:

$\mathrm{H}_{1}$ : Çalışanların psikolojik yıldırmanın iletişime yönelik saldırı davranışlarına maruz kalmaları ile verimlilikleri arasında negatif bir ilişki vardır. 
$\mathrm{H}_{2}$ : Çalışanların psikolojik yıldırmanın sosyal ilişkilere yönelik saldırı davranışlarına maruz kalmaları ile verimlilikleri arasında negatif bir ilişki vardır.

$\mathrm{H}_{3}$ : Çalışanların psikolojik yıldırmanın sosyal konuma yönelik saldırı davranışlarına maruz kalmaları ile verimlilikleri arasında negatif bir ilişki vardır.

$\mathrm{H}_{4}$ : Çalışanların psikolojik yıldırmanın mesleki ve özel yaşamın niteliğine yönelik saldırı davranışlarına maruz kalmaları ile verimlilikleri arasında negatif bir ilişki vardır.

$\mathrm{H}_{5}$ : Çalışanların psikolojik yıldırmanın sağlığa yönelik saldırı davranışlarına maruz kalmaları ile verimlilikleri arasında negatif bir ilişki vardır.

Psikolojik yıldırmaya maruz kalma durumu ile çalışan verimliliği arasındaki ilişkilere dair öne sürülen hipotezlerin test edilmesinde, anket yöntemi ile bir saha araştırması yürütülmüştür. Araştırmada kullanılan anket formunun oluşturulmasında ilgili literatürde belirtilen hususlar dikkate alınmış olup, ilgili ölçekler uyarlanarak forma dâhil edildikten sonra saha çalışmasına geçilmiştir. Ölçekler 1 kesinlikle katılmıyorum ve 5 kesinlikle katılıyorum olmak üzere 5 'li Likert tipi ölçekler halinde düzenlenmiştir. İletişime yönelik saldırılar ( 8 ifade), sosyal ilişkilere saldırılar ( 5 ifade), sosyal konuma saldırılar (10 ifade), mesleki ve sosyal yaşamın niteliğine yönelik saldırılar (9 ifade), sağlığa yönelik saldırılar (5 ifade) olmak üzere beş alt boyut içeren psikolojik yıldırma algısına ilişkin ölçeklerin uyarlanmasında Leymann'ın Psikolojik Terör Envanterinde yer alan maddelerin Tınaz’ın (2011) kullandığı Türkçe karşılıkları ile beraber literatürde kalıplaşmış kullanımlar dikkate alınmıştır. Leymann'ın ölçeğinin Cronbach $\alpha$ değeri 0,91 olarak belirtilmiştir (Dikmetaş, Top ve Ergin 2011). Çalışan verimliliğini (6 ifade) içeren ölçekler Turan (2006) tarafından Dalal vd. (2003)'den uyarlanarak demografik özellikleri içeren kısa bir bölüm ile birlikte formda yer almıştır. İlgili ölçeğin Cronbach $\alpha$ değerinin 0,81 olduğu görülmektedir.

$\mathrm{Bu}$ araştırmanın saha çalışması, Manisa OSB sınırları içerisinde yer alan küçük ve orta büyüklükteki yerli imalat firmalarını kapsamaktadır. Saha çalışmasında öncelikle Manisa OSB web sitesinden firma bilgileri taranmıştır. Bu tarama sirasında \%100 yabancı sermayeli firmalar, yabanc1 ortaklı firmalar, Türkiye'nin ilk ve ikinci 500 büyük sanayi kuruluşu arasında yer alan bölge firmaları elendikten sonra geriye kalan küçük ve orta ölçekli 113 imalat firmasından tesadüfi örnekleme yöntemi ile seçilmiş 100 fïrmadan yönetici pozisyonlarında bulunmayan idari personele ulaşabilmek amaçlanmıştır ${ }^{1}$. İlgili firmalardan yönlendirilen birer kişi ile yüz yüze ve telefon görüşmeleri ile randevu istenmiştir. Yapılan görüşmelerde bu firmalardan 7 tanesi çalışmanın firma bünyesinde yapılmasına ilk görüşmede izin vermediğini belirtmiştir. Geriye kalan 93 firma yetkilisi ile formların çalışanlarına elektronik ortamda iletilmesi ve gönüllü olarak çalışmaya katılmak isteyecek personelin doldurduğu formu direk

\footnotetext{
${ }^{1}$ MOSB yönetimi şirketlere ait sayısal verileri veremeyeceklerini belirtmiş olmakla beraber, iletişim kurulabilen şirketlerden de çoğu personel sayıları hakkında net bilgi vermekten kaçınmıştır. Dolayısıyla evren tam olarak bilinememektedir. Bu sebeple, çalışmada örneklem yerine "çalışma grubu" teriminin kullanılması daha uygun görülmüştür.
} 
olarak araştırmacıya iletmesi yönünde anlaşma sağlanmıştır. Ancak, takip eden telefon aramaları ve eposta yazışmalarında bazı firmalarla bir daha hiç iletişim kurulamışken, bazı firma yetkilileri araştırmanın firma içinde yapılmasının üst yönetim/patron tarafından kabul edilmediğini bildirmiş, bazı firma yetkilileri ise iş yoğunluğunu bahane göstererek firma olarak araştırmaya destek veremeyeceklerini belirtmiştir. Araştırmaya konu olan ilgili firmalardaki idari kadrolarda toplamda tam olarak kaç kişinin çalışmakta olduğuna dair çalışma evrenini gösterecek net bir sayı alınamamıştır. Sonuç olarak, çalışanlarına anketleri elektronik olarak ilettiklerini ve araştırmaya gönüllü olarak katılmak isteyenlerin araştırmacıya direk ulaşacağını belirten firmadan, toplamda 102 yönetici pozisyonlarında bulunmayan idari personel araştırmaya katılmış olup (çalışma grubu \%95 güven aralığında \%10 hata payı ile kabul edilebilirdir), kullanılamayacak anketler elendiğinde geriye kullanılabilir durumda 92 anket formu kalmıştır. Katılımcıların \%56's1 erkek, $\% 51$ 'i evli, \%65'i üniversite mezunu olup \%63'ü şirkette 1-5 yıl arası çalışmakta ve $\% 52$ 'si toplamda 5 yıl ve üzeri sektör deneyimi sahibidir. 25 altı yaş grubunda çalışan oranı $\% 6$ 'da kalırken $25-29,30-34$ ile 35 ve üstü yaş grubu $30 \%$ 'lar seviyesinde görülmektedir. Saha çalışması sonrası elde edilen verilen SPSS 20.0 istatistik programında analiz edilmiştir.

\section{Faktör Analizi ve Temel İstatistikler}

Verilerin faktör analizine uygunluğunu değerlendirmek amacıyla öncelikli olarak Kaiser-Meyer-Olkin (KMO) ve Bartlett testi yapılmıştır. İyi bir faktör analizi için minimum KMO indeks değerinin 0,60 olduğu belirtilmişken 0,90'dan yüksek olması mükemmel olarak belirtilmiştir. Bartlett testinin anlamlı çıkması verilerin faktör analizi için uygunluğunu göstermektedir. Bu testin sonucunda psikolojik yıldırma boyutları için KMO değeri 0,918 ve Bartlett testi anlamlı bulunmuştur $(\chi 2=2417,555, \mathrm{df}=351, \mathrm{p}<0,000)$. Çalışan verimliliği boyutu için ise KMO değeri 0,896 ve Bartlett testi anlamlı bulunmuştur $(\chi 2=396,963$, df $=15$, $\mathrm{p}<0,000)$. KMO değerleri ve Bartlett testlerinin anlamlı bulunması, çalışma grubunun büyüklüğünün yeterli ve elde edilen verilerin faktör analizi için uygun olduğunun bir göstergesi olarak kabul edilmiştir. Bu bulgular sonucu faktör analizine geçilmiştir.

Uygulamada yer alan psikolojik yıldırma ve çalışan verimliliği kavramları için ayrı ayrı faktör analizi yapılmıştır. Psikolojik yıldırma iletişime yönelik saldırı, sosyal ilişkilere saldırı, sosyal konuma saldırı, mesleğe yönelik saldırı ve sağlığa yönelik saldırılar olmak üzere beş boyutlu olarak beklenirken, çalışan verimliliği tek boyut olarak beklenmektedir.

Psikolojik yıldırma ile ilgili 37 ifade kullanılmış olup, faktör analizi sonucunda 5 faktörlü bir sonuca ulaşılmıştır. Sağlığa yönelik saldırılar alt boyutuna ait ifadeler faktör yapısını bozduğu için bir bütün olarak analizden çıkartılırken, diğer bazı ifadeler de (5 ifade) faktör yapısına uygun olmadığ için analiz dışı bırakılmıştır. Bazı değişkenler ise beklenilen boyutun dışında bir başka boyutun altında yer alması sebebi ile içerik geçerliliği onaylandıktan sonra ilgili boyutun değişkeni olarak kabul edilmiştir. Bu işlemler sonucunda, Tınaz'ın (2011) çalışmasındaki faktör isimlendirmeleri faktör dağılımı ve ifadelerin içerikleri 
değerlendirilerek bu çalışmada yeniden adlandırılmıştır. Buna göre, birinci boyut itibara saldırı (7 ifade), ikinci boyut ilişkilere saldırı (7 ifade), üçüncü boyut iletişime saldırı (4 ifade), dördüncü boyut yapılan işe saldırı (5 ifade) ve beşinci boyut kişisel yetkinliğe saldırı (4 ifade) olarak yeniden adlandırılmıştır. Beklenen "mesleki ve özel yaşamın niteliğine yönelik saldırı" ifadelerinin faktör analizi sonucunda mesleğe saldırı ve kişisel yetkinliğe saldırı olarak kendi içerisinde iki boyuta ayrıldığı görülmüştür. Çalışan verimliliğine ilişkin ifadelere faktör analizi yapıldığında beklendiği gibi tek boyutlu olduğu görülmüştür. Bu bölümde yer alan ifadelerin hiçbiri faktörü bozucu etki yaratmadığı için ölçekten çıkarılmamıştır.

Faktör analizi sonucunda psikolojik yıldırmaya ait 5 boyutlu ve çalışan verimliliğine ait tek boyutlu faktör yapıları ve faktör yükleri Tablo 1'de sunulmuştur. Psikolojik yıldırma değişkenine ait faktör yükleri tatmin edici düzeyde olup, 5 boyutlu psikolojik yıldırma değişkeni toplam varyansın \% 77,60'1nı açıklamaktadır. Çalışan verimliliğine ait tek boyutlu faktör yapısı ve ifadelerin faktör yükleri incelendiğinde yükleri tatmin edici düzeyde olup, tek boyutlu verimlilik değişkeni toplam varyansın \%71,93’ünü açıklamaktadır.

Tablo 1: Temel Değişkenlere Ait Faktör Analizleri

\begin{tabular}{|c|c|c|c|}
\hline Temel Değişkenlere Ait Faktörler ve İfadeler & $\begin{array}{l}\text { Faktör } \\
\text { Yükleri }\end{array}$ & $\begin{array}{l}\text { Cronbach } \\
\text { Alfa }\end{array}$ & $\begin{array}{c}\text { Toplam } \\
\text { Açklanan } \\
\text { Varyans }\end{array}$ \\
\hline PSİKOLOJIKK YILDIRMA & & & 77,602 \\
\hline FAKTÖR 1. İtibara Saldırı (7 ifade) & & ,929 & \\
\hline $\begin{array}{l}\text { Çalışmakta olduğum kurumda politik görüšlerim ve dini } \\
\text { inançlarım eleştiriliyor, alay konusu yapılıyor. }\end{array}$ & ,798 & & \\
\hline Çalışmakta olduğum kurumda etnik kökenimle alay ediliyor &, 798 & & \\
\hline $\begin{array}{l}\text { Çalışmakta olduğum kurumda tedavi olmam amaciyla } \\
\text { psikiyatriste/psikologa gitmeye zorlanıyorum. }\end{array}$ &, 730 & & \\
\hline Çalışmakta olduğum kurumda özel yaşantım eleştiriliyor & ,716 & & \\
\hline $\begin{array}{l}\text { Çalışmakta olduğum kurumda el, kol hareketlerimle, } \\
\text { yürüyüşümle, sesimle taklit edilip alay ediliyor. }\end{array}$ & ,679 & & \\
\hline $\begin{array}{l}\text { Çalışmakta olduğum kurumda herhangi bir özrümle alay } \\
\text { ediliyor. }\end{array}$ & 662 & & \\
\hline $\begin{array}{l}\text { Çalışmakta olduğum kurumda akıl hastası olduğum ima } \\
\text { ediliyor. }\end{array}$ & ,650 & & \\
\hline FAKTÖR 2. İlişkiye Saldırı (7 ifade) & & ,933 & \\
\hline $\begin{array}{l}\text { Çalışmakta olduğum kurumda arkadaşlarım bilinçli olarak } \\
\text { benimle iletişim kurmak istemiyorlar. }\end{array}$ & ,781 & & \\
\hline Çalışmakta olduğum kurumda görmezden geliniyorum. & 715 & & \\
\hline Çalışmakta olduğum kurumda bana iftira atılıyor. & ,678 & & \\
\hline $\begin{array}{l}\text { Çalışmakta olduğum kurumda iş yerinde çalışma } \\
\text { arkadaşlarımla görüşmem yönetim tarafından engelleniyor. }\end{array}$ & ,662 & & \\
\hline $\begin{array}{l}\text { Çalışmakta olduğum kurumda sözüm sürekli kesiliyor, } \\
\text { konuşmam engelleniyor. }\end{array}$ & 651 & & \\
\hline $\begin{array}{l}\text { Çalışmakta olduğum kurumda çalışma arkadaşlarımdan } \\
\text { uzakta bir ofiste çalışmak zorunda bırakılıyorum. }\end{array}$ & 564 & & \\
\hline $\begin{array}{l}\text { Çalışmakta olduğum kurumda düzenlenen organizasyonlara } \\
\text { davet edilmiyorum. }\end{array}$ & ,515 & & \\
\hline FAKTÖR 3. İletişime Saldırı (4 ifade) & & 881 & \\
\hline $\begin{array}{l}\text { Çalışmakta olduğum kurumda meslektaşlarım ve veya } \\
\text { birlikte çalıştı̆̆ım kişiler kendimi ifade etmemde engeller } \\
\text { koyuyorlar. }\end{array}$ & ,820 & & \\
\hline $\begin{array}{l}\text { Çalışmakta olduğum kurumda üstlerim kendimi ifade etmemi } \\
\text { engelliyorlar. }\end{array}$ & ,711 & & \\
\hline
\end{tabular}




\begin{tabular}{|c|c|c|c|}
\hline $\begin{array}{l}\text { Çalışmakta olduğum kurumda diğer çalışanlar yanında } \\
\text { bilinçli olarak aşağılanıyorum. }\end{array}$ & ,708 & & \\
\hline $\begin{array}{l}\text { Çalışmakta olduğum kurumda yaptığım işler diğer çalışanlar } \\
\text { tarafından sürekli olarak eleştiriliyor. }\end{array}$ & ,573 & & \\
\hline FAKTÖR 4. Yapılan İşe Saldırı (5 ifade) & & ,926 & \\
\hline Çalışmakta olduğum kurumda anlamsız görevler veriliyor. & ,839 & & \\
\hline $\begin{array}{l}\text { Çalışmakta olduğum kurumda sorumlu olmadığım konularda } \\
\text { tenkit ediliyorum. }\end{array}$ & ,734 & & \\
\hline $\begin{array}{l}\text { Çalışmakta olduğum kurumda özgüvenimi olumsuz } \\
\text { etkileyecek görevler veriliyor. }\end{array}$ & ,638 & & \\
\hline $\begin{array}{l}\text { Çalışmakta olduğum kurumda sürekli yapmam gereken işleri } \\
\text { yapamadığım, kapasitemin yetersiz olduğu ima ediliyor. }\end{array}$ & 607 & & \\
\hline $\begin{array}{l}\text { Çalışmakta olduğum kurumda çabalarım ve başarılarım } \\
\text { haksız bir şeklide değerlendiriliyor. }\end{array}$ & ,577 & & \\
\hline FAKTÖR 5. Kişisel Yetkinliğe Saldırı (4 ifade) & & ,827 & \\
\hline $\begin{array}{l}\text { Çalışmakta olduğum kurumda bilinçli olarak kapasitemin } \\
\text { altında görevler veriliyor. }\end{array}$ & ,776 & & \\
\hline $\begin{array}{l}\text { Çalışmakta olduğum kurumda bilinçli olarak iş verilmediği } \\
\text { için boşa geçen zamanlarım oluyor. }\end{array}$ & ,700 & & \\
\hline Çalışmakta olduğum kurumda yazılı tehdit aldım/alıyorum. & ,644 & & \\
\hline $\begin{array}{l}\text { Çalışmakta olduğum kurumda bilinçli olarak aşağılayıcı, } \\
\text { küçük düşürücü işler yapmak zorunda bırakılıyorum. }\end{array}$ & ,491 & & \\
\hline ÇALIŞAN VERİMLÍLİ̈̇́ & & & 71,934 \\
\hline FAKTÖR 1. Çalışan Verimliliği (6 ifade) & & ,921 & \\
\hline İşlerimi yapacak enerji/motivasyon bulamıyorum. & ,933 & & \\
\hline $\begin{array}{l}\text { İşimi yaparken yapabileceğimin altında bir performans } \\
\text { sergiliyorum. }\end{array}$ &, 883 & & \\
\hline Mesai saati başladığında hemen işime odaklanamıyorum. & ,865 & & \\
\hline İşim ile doğrudan ilgisi olmayan şeylerle uğraşıyorum. & ,856 & & \\
\hline Gün içerisinde yapmam gereken işleri erteliyorum. & ,801 & & \\
\hline Yöneticimin emirlerine uymadım/uymuyorum. & ,737 & & \\
\hline
\end{tabular}

Araştırma ölçeklerinin içsel tutarlılığı ve dengeli bulguları ortaya çıkarıp çıkarmadığına ilişkin Cronbach alfa güvenilirlik testi uygulanmıştır, çünkü eğer ölçeklerde bir güvenilirlik sorunu varsa ölçümüz rastlantısal bir hata üretmiş olabilir (Erdoğan, 2007). Tablo 1'den de anlaşılacağı üzere Cronbach alfa değerlerinin 0,827 ile 0,933 arasında hesaplanmış olması içsel tutarlılıklarının olduğunu göstermektedir ( 0,70 değerinin üstünde olması gerekmektedir).

Faktör analizi ve güvenilirlik testlerinden sonra beş boyut olarak değerlendirilen psikolojik yıldırmaya ve tek boyut olarak değerlendirilen çalışan verimliliğine ait boyutların ortalama değerleri ve standart sapmaları hesaplanmış, değişkenler arasındaki birebir ilişkilerin anlamlı olup olmadığına yönelik korelasyon analizi yapılmıştır (Tablo 2). 5'li likert tipi ölçekle yapılan çalışmada ortalamalar incelendiğinde psikolojik yıldırma davranışlarına çok maruz kalmamış oldukları görülmektedir. Çalışan verimliliğinde ise neredeyse nötr sayılabilecek bir eğilim sergiledikleri görülmektedir. Değişkenlere ait standart sapma değerleri 1,08 ile 0,72 arasında hesaplanmış olup bu değerler arasındaki varyans (değişkenlik) miktarının, geçerli analizin yapılması için yeterli seviyede olduğu görülmektedir. Tablo 2'de sunulan korelasyon katsayıları ile hipotezlerde ileri sürülen ilişkilerin anlamlı olup olmadığını ve ilişkilerinin kuvvetli olup olmadığını belirlemektedir ve yapılan hesaplamalar sonucunda değişkenler arasında ( $<<0,01$ seviyesinde) anlamlı birebir ilişkiler vardır. 
Tablo 2: Ortalama Değer, Standart Sapma ve Korelasyon Değerleri

\begin{tabular}{|l|c|c|c|c|c|c|c|}
\hline Boyutlar & Ort. & SS. & $\mathbf{2}$ & $\mathbf{3}$ & $\mathbf{4}$ & $\mathbf{5}$ & $\mathbf{6}$ \\
\hline 1-İletişime Saldırı & 1,96 &, 90 &, $645^{* *}$ &, $690^{* *}$ &, $640^{* *}$ &, $758^{* *}$ &, $545^{* *}$ \\
\hline 2-Kişisel Yetkinliğe Saldırı & 1,71 &, 76 & 1 &, $698^{* *}$ &, $672^{* *}$ &, $635^{* *}$ &, $534^{* *}$ \\
\hline 3-İlişkiye Saldırı & 1,70 &, 78 & & 1 &, $763^{* *}$ &, $734^{* *}$ &, $647^{* *}$ \\
\hline 4-İtibara Saldırı & 1,56 &, 72 & & & 1 &, $647^{* *}$ &, $593^{* *}$ \\
\hline 5-Yapılan İş̧e Saldırı & 2,15 & 1,05 & & & & 1 &, $635^{* *}$ \\
\hline 6-Çalışan Verimliliği & 2,46 & 1,08 & & & & & 1 \\
\hline$* *$ p $<0,01$ & & & & & &
\end{tabular}

Psikolojik yıldırma değişkeninin alt boyutları arasında en güçlü birebir ilişki ilişkiye saldırı ile itibara saldırı arasında (r: 0,763 ; $\mathrm{p}<0,01)$ ortaya çıkarken, en zayıf birebir ilişki ise kişisel yetkinliğe saldırı ile yapılan işe saldırı arasında (r: $0,635 ; \mathrm{p}<0,01)$ ortaya çıkmıştır. Çalışmada bağımsız değişken olarak ele alınmakta olan psikolojik yıldırmanın alt boyutları ve bağımlı değişken olarak ele alınan çalışan verimliliği arasındaki ilişki incelendiğinde çalışan verimliliği ile en güçlü birebir ilişkinin ilişkiye saldırı ( $\mathrm{r}: 0,647 ; \mathrm{p}<0,01)$, en zayıf ilişkinin ise kişisel yetkinliğe saldırı ( $\mathrm{r}: 0,534 ; \mathrm{p}<0,01)$ ile ortaya çıktığı görülmüştür.

\section{Hipotez Testleri}

Araştırma kapsamındaki hipotezleri test etmek üzere çoklu regresyon analizi kullanılmıştır. Regresyon analizinde yer alan $\mathrm{F}$ değeri, modelin bir bütün halinde anlamlılığını gösteren bir değerdir. $\mathrm{R}^{2}$ değeri ise (belirlilik veya tanımlayıcılık katsayısı) bağımlı değişkendeki değişimin bağımsız değişkenler tarafından ne oranda tanımlanabildiğini ortaya koyan bir ölçüdür.

Psikolojik yıldırma davranışı alt boyutlarında verimlilik üzerine bir etki olup olmadığı ya da nasıl bir etki olduğunu test edebilmek amacı ile çoklu regresyon analizi uygulanmıştır. Çoklu regresyon analizine ait bulgular Tablo 3 'te sunulmuştur. Tablo 3'te görüldüğü üzere model $\mathrm{p}<0,01$ seviyesinde bir bütün olarak anlamlıdır (F:16,301). $\mathrm{R}^{2}$ değeri 0,698 olarak bulunmuştur. Buna göre çalışan verimliliğini, modeldeki bağımsız değişkenlerin tümü $\% 69,8$ oranında açıklayabilmektedir.

Tablo 3: Psikolojik Yıldırma Boyutlarının Çalışan Verimliliği Üzerindeki Etkilerine Yönelik Regresyon Analiz Sonuçları

\begin{tabular}{|l|c|c|c|c|c|}
\hline \multicolumn{1}{|c|}{ Boyutlar } & Beta & T & p & Tolerans & VIF \\
\hline İletişime Saldırı &,- 008 &,- 063 &, 950 &, 363 & 2,755 \\
\hline Kişisel Yetkinliğe Saldırı &, 046 &, 391 &, 697 &, 430 & 2,324 \\
\hline İlişkiye Saldırı &, 272 & 1,901 &, 061 &, 293 & 3,416 \\
\hline İtibara Saldırı &, 160 & 1,258 &, 212 &, 369 & 2,713 \\
\hline Yapılan İşe Saldırı &, 309 & 2,313 &, 023 &, 335 & 2,983 \\
\hline $\mathrm{R}^{2}:, 698$ F: 16,301 p: ,000 & \multicolumn{5}{|l}{} \\
\hline
\end{tabular}

VIF değeri 5 'ten yüksek ve tolerans değeri de 0,20 'den küçük olması, çoklu birlikte değişkenlik (multicollinearity) sorunu olduğuna dair bir gösterge olarak algılanmaktadır. Çalışmada yapılan regresyon analizinde belirtilen tolerans ve VIF değerleri göz önünde tutulduğunda çoklu birlikte değişkenlik durumu ile karşılaşılmamış olduğu görülmektedir. Psikolojik yıldırma alt boyutlarından sadece yapılan işe saldırı $(\beta: 0,309 ; \mathrm{p}<, 05)$ ve ilişkiye saldırı $(\beta: 0,272 ; \mathrm{p}<, 05)$ 
değişkenlerinin çalışan verimliliği üzerinde aynı yönlü ve anlamlı etkileri olduğu bulunmuştur. $\mathrm{Bu}$ sonuçlara göre, yapılan işe saldırılarda 1 birimlik bir artışın çalışan verimliliğini 0,309 oranında arttırıyor olması, ilişkilere saldırılarda 1 birimlik artışın ise 0,272 oranında arttırıyor olması beklenmektedir. Diğer üç değişken incelendiğinde ise çalışan verimliliği üzerinde istatistiksel olarak anlamlı etkilerinin bulunmadığı görülmüştür.

\section{SONUÇ, TARTIŞMA VE ÖNERILER}

$\mathrm{Bu}$ çalışma psikolojik yıldırma olgusunun çalışan verimliliği üzerindeki etkisini incelemeyi amaçlamaktadır. Bu doğrultuda Manisa OSB'de imalat yapan KOBİ'lerde yönetici pozisyonlarında bulunmayan idari personel üzerinde anket yöntemi ile bir saha çalışması gerçekleştirilmiş ve çalışanların psikolojik yıldırmaya maruz kalmaları ile bunun çalışanların verimlilikleri üzerindeki etkisi saptanmaya çalışılmıştır. Ülkemizde psikolojik yıldırma kavramı genellikle örgütsel bağlılık ve işten ayrılma niyeti üzerindeki etkisi, psikolojik yıldırma davranışlarını uygulayanın özellikleri gibi kavramlarla bir arada incelenmiştir. Türkiye'de yürütülmüş olan ampirik çalışmalardan çok azı psikolojik yıldırma ve verimlilik/verimlilik karşıtı davranışları bir arada incelemiş olup (örneğin Turan, 2006; Demir \& Çavuş, 2009), ilgili çalışmalar hizmet sektörünü ele almışlardır. Bu çalışma, hizmet sektörü çalışanlarına benzer şekilde üretim firmalarının idari personelinin de daha sık psikolojik yıldırmaya maruz kaldığından hareketle, üretim firmalarındaki idari personel üzerinden psikolojik yıldırmanın çalışan verimliliği ile ilişkisini incelemesi açısından önemlidir. Dolayısıyla bu çalışma, ülkemizde işyerinde psikolojik yıldırma kavramının çalışan verimliliği ile ilişkisi farklı bir çalışma grubu üzerinde nicel olarak sınayan sayılı çalışmalardan biridir.

Araştırmaya katılan çalışanların psikolojik yıldırmaya maruz kalmaları ile verimlilikleri arasındaki ilişki korelasyon analizi ile incelendiğinde tüm psikolojik yıldırma davranışları boyutlarının verimlilik ile anlamlı düzeyde ilişkili olduğu görülmektedir. Araştırma modeli psikolojik yıldırma davranışları ve verimlilik değişkenlerinin birbiriyle ilişkisini ortaya koyma açısından desteklenmiştir.

Analiz sonuçları birlikte değerlendirildiğinde çalışmanın başında belirtilen hipotezlerin kısmen desteklendiği görülmektedir. "H5. Çalışanların psikolojik yıldırmanın sağlığa yönelik saldırı davranışlarına maruz kalmaları ile çalışan verimliliği arasında ilişki vardır" hipotezi, sağlığa yönelik saldılar alt boyutu ifadeleri faktör analizinde çıkartıldığ 1 için test edilememiştir. Diğer hipotezlerde de adlandırmalardan dolayı değişiklikler meydana gelmiştir. Sonuç olarak yapılan analiz sonuçlarına ait bulgular Şekil 1'de özetlenerek sunulmuştur. 
SSekil 1. Psikolojik Yıldırma Boyutlarının Çalıșan Verimliliği Üzerindeki Etkileri

\begin{tabular}{|c|c|c|}
\hline İletişime Saldırı & & \\
\hline Kișisel Yetkinliğe Saldırı & $\beta:, 272^{* *}$ & \\
\hline İlişkiye Saldırı & & $\begin{array}{l}\text { Çalışan } \\
\text { Verimliliŏ̆i }\end{array}$ \\
\hline İtibara Saldırı & & \\
\hline Yapılan İșe Saldırı & & \\
\hline
\end{tabular}

Psikolojik yıldırmaya maruz kalmanın verimlilik üzerindeki etkisini saptayabilmek amacı ile ortaya konan hipotezlerin testi için regresyon analizleri yapılmıştır. Analiz sonucuna göre, seçilen çalışma grubu dâhilinde psikolojik yıldırmanın iki alt boyutu olan ilişkiye saldırının ve yapılan işe saldırının çalışan verimliliği üzerinde anlamlı ve olumlu etkileri olduğuna dair bulgulara ulaşılmıştır.

Daha önce psikolojik yıldırma davranışlarının çalışan verimliliği üzerine etkisini inceleyen çalışmalara çok rastlanmamakla birlikte, yakın değişkenleri analiz etmiş çalışma sonuçlarına bakıldığında, psikolojik yıldırmanın genel olarak çalışan verimliliği üzerinde anlamlı ve olumlu etkisinin olması beklenmemektedir. Psikolojik yıldırma beş alt boyutunun verimlilik karşıtı davranışlarla ilişkisini Pearson korelasyon testi ile inceleyen Turan (2006) çalışması bulguları, çalışanların çalışma hayatlarında nadiren verimlilik karşıtı davranışlar sergilediğini; psikolojik yıldırmaya maruz kaldıklarında verimlilik karşıtı davranış sergileme sıklıklarının arttığını göstermektedir. Psikolojik yıldırma boyutlarının kişisel iş performansı ile ilişkilerinin sorgulandığı bir başka çalışmada (Demir \& Çavuş, 2009) ise itibara saldırı boyutunun kişisel performansı olumsuz şekilde etkilediği bulgusuna ulaşmıştır.

Pek çok çalışma psikolojik yıldırmanın iş tatmininde azalmaya yol açtı̆̆ını dair bulgular sunmaktadır (Çalışkan ve Tepeci, 2008). Ancak çalışanların daha iyi bir alternatifleri olmadığına inandıkları sürece mevcut işyerlerinden ayr1l(a)madıkları da görülmektedir (Divincova \& Sivakova, 2014). Daha "iyi bir alternatif" bireysel yetkinlikler bağlamında düşünülebileceği gibi çalışanın yaşadığı ülke ve ekonomik koşullar bağlamında da ele alınmalıdır. Literatürde psikolojik yıldırma ile ilgili çalışmalarda ekonomik gelişmişlik seviyeleri yüksek Batı ülkelerinin baskınlığı göze çarpmaktadır ki çalışma bulguları değerlendirilirken bu bağlamın da göz ardı edilmemesi gerekmektedir. Türkiye gibi işsizlik oralarının yüksek seviyelerde görüldüğü ülkelerde işten ayrılması durumunda çalışanın yeni bir iş bulmaya olan inancı düşük olabilecektir. $\mathrm{Bu}$ doğrultuda, mevcut işyerinde çalışmaya ve kendisine verilen görevleri uğradığ 1 kötü muameleye rağmen mümkün olduğunca iyi şekilde yerine getirmeye gayret etmesi olağan gözükmektedir. Bu şekilde işten ayrılmaya cesaret gösteremediği gibi işten çıkartılmasını da önlemeye çalışabilecektir. Böyle bir durumda işyerinde bir çalışan ile bilinçli olarak iletişim kurulmaz, görmezden gelinir kısacası o birey iş ortamından izole edilir ise bu davranışlara maruz kalan birey de sadece işine odaklanabilir, yapması gereken işleri zamanında yaparak bireysel verimliliğini 
arttırabilir. Bir başka açıdan bakıldığında ise çalışana yaptı̆̆ 1 işlerde yetersiz olduğu ima edilir, çabaları veya başarıları sürekli eleştirilir ise bu çalışan kendini ispatlamak, daha iyisini yapıp övgü almak için yapması gereken işlerin daha da iyisini yapabilir ve böylelikle bir seviyeye kadar çalışan verimliliği artabilir. Bu görüşü destekler şekilde banka çalışanları üzerine yapılmış olan bir araştırmada itibara ve özel hayata yönelik psikolojik şiddet algısı değişkenleri kişisel başarıda azalma düzeyinin belirleyicisi olarak ifade edilmiş olup bu ilişkinin açıklayıcılık gücünün zayıf olduğu vurgulanmıştır. Bu araştırmada, çalışanlarının itibara ve özel hayata yönelik psikolojik şiddet algısı düzeylerinin işten ayrılma niyeti düzeylerini etkilemediği ifade edilmiştir. Hatta psikolojik şiddet algısı düzeylerinin, iş, işyerinde iletişim, itibar ve özel hayata yönelik psikolojik yönüyle düşük düzeyde olması, tükenmişlik düzeyinin zaylf düzeyde bulunması ve işten ayrılma niyetinin zayıf düzeyde gerçekleşmesi kişi, iş, iş yaşamı açısından olumlu olarak değerlendirilmiştir (Tanrıverdi vd., 2018). Malatya ilinde iletişim ve çağrı merkezlerinde çalışan müssteri temsilcileri üzerine yapılan bir çalışmada psikolojik yıldırma bulgularına rastlanmaktadır. Bu çalışmadaki mağdurlar huzursuz bir çalışma ortamı ve arkadaşlık ilişkilerinin onları olumsuz yönde etkilediğini vurgulamakla beraber kendi iş performanslarından memnun olduklarını da belirtmektedirler (Duman \& Akdemir, 2016). Maruz kalınan psikolojik saldırılar üstten gelmiyorsa ve henüz sağlığ 1 tehdit edecek boyutlara ulaşacak kadar uzun dönem maruz kalınmadı ise literatürü destekler şekilde mağdur bu tip olumsuz davranışların psikolojik saldırı olduğunu fark etmemiş olabilir hatta kendisini kanıtlamak için daha çok çaba sarf etmeyi tercih etmiş olabilir. Dolayısıyla psikolojik saldırıya kimin tarafından maruz kaldığı, ne kadar süredir maruz kaldığı, kurbanın kişilik özellikleri ve hangi boyutlara yönelik saldırılara maruz kaldığı gibi farklı etmenleri bir arada içeren gelecek çalışmaların yapılması bulguları daha iyi değerlendirebilmek için faydalı olabilecektir. Hatta bu tip bulgular kültür bağlamında değerlendirilmelidir.

Hofstede (1980) ve House vd. (2001) Doğu ve Batı arasındaki kültürel farklılıkları 1980'lerden sonra net şekilde ortaya koymuş olup, Bodur ve Kabasakal (2002) iş yaşamı ve liderlik şekillerinde de kültürel farklılıkların kendisini gösterdiğini belirtmektedir. GLOBE proje bulguları Türkiye'yi Orta Doğu kümesine yerleştirirken, bu kümeyi düşük gelecek yönelimi, düşük cinsiyetler aras1 eşitlik, yüksek grup içi toplulukçuluk, yüksek güç mesafesi ve orta seviyede kurumsal toplulukçuluk, insani yaklaşım, performans yönelimi ve atılganlık ile tanımlamaktadır (House vd., 2004, s.191). Ailenin önemi, kendini ailenin ismi ile tanıtma, belirli bir gruba aidiyet hissetme, babaya kayıtsız sayg, erkeklerin kadınlara üstünlüğünü kabul etme, lider konumdakilerin söylediklerine sadakatle uymak ve ne olursa olsun bunu kadere bağlayabilmek İslami geleneğin ve inanışın bir parçası olarak kabul edilmektedir (Kabasakal \& Bodur, 2002). Dolayısıyla, Batı orijinli bir kavram olarak psikolojik yıldırmanın algılanmasında ve sonuçlarında farklılıklar olabileceği de düşünülmelidir. "Üst”ün söylediklerini sorgusuz kabul etme ve kayıtsız saygı duyma gibi özelliklerden dolayı belki de pek çok çalışan uğradığı muameleyi psikolojik yıldırma olarak düşünmemektedir. Diğer taraftan, 
işyerinde meydana gelen geniş spektrumda olumsuz pek çok durumu psikolojik yıldırma bileşenlerinden olarak da algılayabilecektir. Örneğin lider-üye etkileşimi (Graen \& Uhl-Bien, 1995) bağlamında dış grup içinde kalan çalışanlar mevcut kültürel yapımız içerisinde psikolojik yıldırmaya uğradıklarını hissedebilirler. En çok ve en az algılanan psikolojik yıldırma davranışlarına bu lensten bakıldığında çalışanların önemli olduğunu hissetmediğinde incindikleri, ancak dini/etnik yapısı ile ilgili şakalara tolerans gösterebildikleri görülmektedir (Seçkin-Halaç \& Bulut, 2010), çünkü Türk insanı duygusal olarak çabuk etkilenir yapıdadır. Hatta çalışanların adalet algılarındaki farklılıklar dahi psikolojik yıldırma mağduru olduklarını düşündürtebilmektedir (Fortin, 2008). Dolayısıyla Türkiye'de algılanan psikolojik yıldırma davranışlarının kültürel bağlamda daha iyi analiz edilebilmesi için niteliksel ve derinlemesine yapılacak olan saha çalışmaları hem araştırmacılar hem de uygulayıcılar için önemli katkılar sağlayacaktır.

İşyerinde psikolojik y1ldırmanın örgütsel düzeyde ve ülke ekonomisi bağlamında yarattı̆̆ 1 olumsuzluklar yapılan pek çok çalışmada da vurgulanmış durumdadır. Ancak unutulmamalıdır ki psikolojik yıldırma en çok mağdurları üzerinde hasar yaratan bir insan hakları ihlalidir. Bu sebeple de çalışanların istifa yoluyla kıdem tazminatından vazgeçerek işten ayrılma niyetini arttırmaya yönelik örgütsel kısa dönem kazançlara neden olabilecek bu tip davranışlara karş1 uygulayıcıların daha hassas ve etik bir tavır takınmaları gerekmektedir. Yüksek işsizlik oranları nedeniyle, alternatif bir iş bulmada yaşanan zorluk da çalışanları yapılan saldırıya dayanmak zorunda bırakmakta hatta, bu çalışma bulguları ile düşününce mağdurun kendini ispat çabası ile daha yüksek verimlilik göstermesine de sebep olabilmektedir. Dolayısıyla, Doğu kültüründe sıklıkla rastlandığı için göz ardı edilen ve Batı'da "mobbing" davranışları olarak hukuksal yaptırımlara sebebiyet veren olumsuz işyeri davranışları hakkında daha bilinçli ve duyarlı olunmas1 gerekmektedir.

Çalışmada evren hakkında net bir bilgi alınmadığı ve daha büyük bir çalışma grubuna ulaşılabileceği düşünüldügünde bu çalışma, Manisa OSB KOBİ'lerinde çalışmakta olan yönetici pozisyonlarında bulunmayan personelin özelinde bir eğilim sunmaktadır. Algıya dayalı ve anket çalışması içeren tüm sosyal bilimler çalışmalarında olduğu gibi belli kısıtlar bu çalışma için de geçerlidir. Araştırmada çalışanların, psikolojik yıldırma olgusunu dikkate alarak farklı firmalarda maruz kalmış olabilecekleri eski deneyimlerini anket sorularını yanıtlarken göz ardı etmeleri, soruları yanıtlarken çalışmakta oldukları mevcut firma içerisindeki son bir seneyi göz önüne alarak yanıt vermeleri istenmiştir. Bununla birlikte, güncel olarak psikolojik yıldırmaya maruz kalan kişilerin geçmişte farklı bir örgütte maruz kaldıkları psikolojik yıldırma olgusunu dikkate alarak sorulara yanlı yanıt vermedikleri ve araştırmaya katılan tüm bireylerin soruları aynı şeklide algıladıkları varsayılmıştır. Dahası, beyana ve algıya dayalı her çalışmanın bir kısıtı olarak, psikolojik yıldırma davranışına maruz kalmış personelin hem bu tür davranışlara maruz kaldığını açıklaması hem de algıya dayalı olarak kendi çalışma verimliliği hakkında gerçeği tam olarak yansıtacak cevaplar vermekten kaçınmış olabileceği de düşünülmelidir. 
Çalışmada seçilen çalışma grubu sadece Manisa OSB'nde üretim yapan KOBI'lerde çalışan yönetici pozisyonunda olmayan idari personeli kapsamaktadır. $\mathrm{Bu}$ bölgede her firmaya ulaşılamamıştır ve bu durum çalışmanın kısıtlarından biri olmuştur. Ayrıca çalışma gönüllük esasına dayanmakta olup, görüşülen her firma çalışmaya katılmak istemediğini belirtmiştir. Her anket çalışmasının bir kısıt olarak çalışmaya katılan her bireyin, ifadeleri aynı ve doğru algılayamamış olması da diğer bir kısıt olarak düşünülebilir. Dolayısıyla bu çalışmada elde edilen bulgular için genellemeye gidilmesi yerine, ortaya çıkan bulguların belirtilmiş olan çalışma grubu içindeki eğilimi göstermiş olduğu düşünülmelidir.

\section{KAYNAKÇA}

Acar, O.K, Uzunbacak, H.H \& Irmaklı, S. (2017). KOBİ çalışanlarının mobbinge maruz kalma düzeyinin araştırılması (İkitelli OSB örneği). Journal of Social and Humanities Sciences Research, 4(3): 441-451.

Atman, Ü. (2012). İşyerinde psikolojik terör: Mobbing. Sağllkta Performans ve Kalite Dergisi, 3 : $157-172$

Berry, C. M., Carpenter, N.C. \& Barratt, C.L. (2012). Do other reports of counterproductive work behavior provide an incremental contribution over self-reports? A meta analytic comparison. Journal of Applied Psychology, 97(3): 613-636.

Boddy, C.R. (2014). Corporate psychopaths, conflicts, employee affective well-being and counterproductive work behavior. Journal of Business Ethics, 121: 107-121.

Kabasakal, H. \& Bodur, M. (2002). Arabic cluster: A bridge between East and West. Journal of World Business, 37: 40-54.

Bozbel, S. \& Palaz, S. (2007). İsyerinde psikolojik taciz (mobbing) ve hukuki sonuclari[mobbing in the workplace and its legal consequences]. TISK Akademi, 1: 66-81.

Carbo, J. \& Hughes, A. (2010). Workplace bullying: Developing a human rights definition from the perspective and experiences of targets. The Journal of Labor and Society, 13: 387-403.

Cemaloğlu, N. \& A. Ertürk (2007). Öğretmenlerin maruz kaldıkları yıldırma eylemlerinin cinsiyet yönünden incelenmesi. Türk Ĕgitim Bilimleri Dergisi, 5(2):345-362.

Çalışkan, O. \& Tepeci, M. (2008). Otel işletmelerinde ortaya çıkan yıldırma davranışlarının iş tatmini ve işte kalma niyetlerine etkileri. Anatolia: Turizm Araştırmaları Dergisi, 19 (2): 135-148.

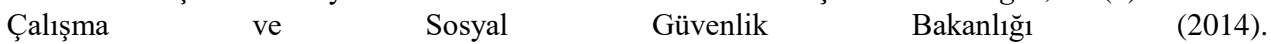
https://www.csgb.gov.tr/media/2053/mobbing_2014.pdf, erişim tarihi: 15.10.2018.

Çobanoğlu, Ş. (2005). Mobbing: İşyerinde duygusal saldırı ve mücadele yöntemleri. İstanbul: Timaş

Davenport, N., Schwartz, R. D. \& Elliot, G.P. (2003). Mobbing: İşyerinde duygusal taciz (Çev: O. C. Önertoy,), İstanbul: Sistem Yayınc1lık

Dikmetaş, E; Top, M. \& Ergin, G. (2011) Asistan Hekimlerin Tükenmişlik ve Mobbing Düzeylerinin İncelenmesi, Türk Psikiyatri Dergisi, 22(3), 137-149.

Divincova, A. \& Sivakova, B. (2014). Mobbing at workplace and its impact on employee performance. Human Resources Management and Ergonomics, 8(2): 20-34.

Demir, Y. \& Çavuş, M.F. (2009). Mobbing' in kişisel ve örgütsel etkileri üzerine bir araştırma. Niğde Üniversitesi IIBFF Dergisi, 2(1): 13-23.

Dikmetaş, E., Top, M. \& Ergin, G. (2011). An examination of mobbing and burnout of residents. Türk Psikiyatri Dergisi, 22(3): 137-149.

Doğan-Kılıç, E. (2009). Psychological violence in learning organizations: A case study in Şanlıurfa, Turkey. Social Behavior and Personality, 37(7):869-880.

Durmuş, S.C, Topcu, İ. \& Yıldırım, A. (2018). Mobbing behaviors encountered by nurses and their effects on nurses. International Journal of Caring Sciences, 11(2): 905-913.

Emerson, R. M. (1976). Social exchange theory. Annual Review of Sociology, 2: 335-362.

Erdoğan, İ. (2007). Pozitivist metodoloji- Bilimsel araştırma tasarımı istatistiksel yöntemler, analiz ve yorumu (2). Ankara: Erk 
Ergun-Ozler, D., Giderler-Atalay, C. \& Dil-Şahin, M. (2008). Mobbing'in örgütsel bağlllık üzerine etkisini belirlemeye yönelik bir araştırma. Dumlupınar Üniversitesi Sosyal Bilimler Dergisi, 22:37-60.

Fettahlığlu, Ö.O (2008). Örgütlerde psikolojik şiddet (mobbing): Üniversitelerde bir uygulama. DEÜ SBE Yayınlanmamış doktora tezi.

Fortin, M. (2008). Perspectives on organizational justice: Concept clarification, social context integration, time and links with morality. International Journal of Management Reviews, 10(2): 93-126.

Fox, S., Spector, P.E. \& Miles, D. (2001). Counterproductive work behavior in response to job stressors and organizational justice: Some mediator and moderator tests for autonomy and emotions. Journal of Vocational Behavior, 59: 291-309.

Gardner, S. \& Johnson, P.R. (2001). The Leaner, meaner workplace: Strategies for handling bullies at work. Employment Relations Today, Summer: 23-36

Graen, G. B. \& Uhl-Bien, M. (1995). Relationship-based approach to leadership: Development of leader-member exchange (LMX) theory of leadership over 25 years: Applying a multi-level multi-domain perspective. Leadership Quarterly, 6(2): 219-247.

Gökçe, A. T. (2008). Mobbing: İşyerinde yıldırma nedenleri ve başa çıkma yöntemleri. Ankara: Öğreti

Gündüz, H. B. \& Yılmaz, O. (2008). Ortaöğretim kurumlarında mobbing (yıldırma) davranışlarına ilişkin öğretmen ve yönetici görüşleri (Düzce örneği), Milli Ĕgitim Dergisi, 179:269-281.

Hoel, H., Rayner, C., \& Cooper, C. L. (1999). Workplace bullying. International Review of Industrial and Organizational Psychology, 14, 189-230

Hofstede, G. (1980) Culture's Consequences: International Differences in Work-Related Values, Beverly Hills, CA: Sage.

House, R., Javidan, M., \& Dorfman, P. W. (2001). Project GLOBE: An introduction. Applied Psychology: An International Review, 50(4), 489-505

House, R. J., \& Javidan, M. (2004). Overview of GLOBE. R. J. House, P.J. Hanges, M. Javidan, P. W. Dorfman, V. Gupta (Ed.), Culture, leadership and organizations (içinde). The GLOBE study of 62 societies (pp. 9-28). Thousand Oaks, CA: Sage Publications.

Huber, B. (1994). Mobbing. Psychoterror am Arbeitsplatz. Niedernhausen: Falken

Hutton, S. \& Gates, D. (2008). Workplace incivility and productivity losses among direct care staff. AAOHN Journal, 56(4), 168-175.

International Labor Organization (ILO), (2002). Framework guidelines for addressing workplace violence in the health sector. Geneva: ILO Publication

International Labor Organization (ILO), (2016). Meeting of Experts on Violence against Women and Men in the World of Work, Geneva: ILO Publication

İzmir, G. \& Fazlıoğlu, A. (2011). İşyerinde psikolojik taciz (mobbing) ve çözüm önerileri komisyon raporu, Kadın Erkek Fırsat Eşitliği Komisyonu Yayınları No.6, TBMM Basımevi: Ankara

Jex, S.M. \& Britt, T.E. (2008). Occupational stress and employee health. Organizational psychology: A scientist-practitioner approach, 199-232.

Jockin, V., Arvey, R.D. \& McGue, M. (2001). Perceived victimization moderates self-reports of workplace aggression and conflict. Journal of Applied Psychology, 86:1262-1269

Kabasakal, H. \& Bodur, M. (2002). Arabic cluster: A bridge between East and West. Journal of World Business, 37: 40-54.

Keskin, A. \& Canbaz, S. (2014). KOBİ'lerde çalışanların mobbinge maruz kalma durumları: Kırklareli ilinde bir araştırma. $\dot{I} U \ddot{U} S B D, 1(2): 161-196$.

Koopman, C., Pelletier, K.R, Murray, J.F., Sharda, C.E. vd. (2002). Stanford presenteeism scale: Health status and employee productivity. Journal of Occupational and Environmental Medicine, 44(1): 14-20.

Köse, S. \& Uysal, Ş. (2010). Kamu personelinin yıldırma (mobbing) ve boyutları hakkındaki düşünceleri üzerine bir çalışma: Manisa Tarım İl Müdürlügü örneği. CBÜ SBE Dergi, 8(1): 261-276

Leymann, H. (1990). Mobbing and psychological terror at workplaces. Violence and Victims, 5(2): 119-126. 
Leyman, H. (1996). The content and development of mobbing at work. European Journal of Work and Organizational Psychology, 5(2): 165-184.

Leymann, H. The Mobbing Encyclopedia. 05.11.2013 www.leymann.se/English/12210E.HTM, www.leymann.se/English/12220E.HTM, www.leymann.se/English/11110E.HTM, www.leymann.se/English/12100E.HTM

Leymann, H. \& Gustafsson, A. (1996). Mobbing at work and the development of post-traumatic stress disorders. European Journal of Work and Organizational Psychology, 5(2): 251-275.

Lim, S., \& Cortina, L.M. (2005). Interpersonal mistreatment in the workplace: The interface and impact of general incivility and sexual harassment. Journal of Applied Psychology, 90(3): 483-496.

Marks, M.L., Hackett, E.J., Mirvis, P.H. \& Grady Jr., J.F. (1986). Employee participation in a quality circle program: Impact on quality of work life, productivity and absenteeism. Journal of Applied Psychology, 71(1): 61-69.

Minibaş-Poussard, J., Seçkin-Çelik, T. \& Bingöl, H.B. (2018). Mobbing in higher education: Descriptive and inductive case narrative analyses of mobber behavior, mobbee responses, and witness support. Educational Sciences: Theory \& Practice, 18(2): 471-494.

Ones, S.D. (2002). Introduction to special issue on counterproductive behaviors at work. International Journal of Selection and Assessment, 10(1/2): 1-4.

Paoli, P. \& Merllie, D. (2001). Third European survey on working conditions, İrlanda: European Foundation.

Pearson, C.M., Andersson, L.M. \& Porath, C.L. (2000). Assessing and attacking workplace incivility. Organizational Dynamics, 29(2): 123-137.

Penney, L.M. \& Spector, P.E. (2005). Job stress, incivility, and counterproductive work behavior (CWB): The moderating role of negative affectivity. Journal of Organizational Behavior, 26: 777-796.

Rayner, C. \& Hoel, H. (1997). A summary review of literature relating to workplace bullying. Journal of Community and Applied Social Psychology, 7: 181-191.

Sabuncuğolu, Z. (2005). İnsan Kaynakları Yönetimi. Bursa: Alfa Aktüel

Seçkin-Çelik, T. \& Minibaş-Poussard, J. (2017). Üniversitelerde psikolojik taciz: Araştırma görevlisi ve yardımcı doçentlere yönelik bir araştırma. Finans Politik \& Ekonomik Yorumlar, 54(629): 103-119.

Seçkin-Halaç, D. \& Bulut, C. (2010). Mobbing: A review of Turkish literature. $11^{\text {th }}$ Management International Conference (MIC), Kasım, Ankara

Sloan, M. L., Matyok, T., Schmitz, C.L \& Short, G.F.L. (2010). A Story to tell. Bullying and mobbing in the workplace. International Journal of Business and Social Science, 1(3): 87-97.

Spector, E.P. \& Fox, S. (2005). The stressor-emotion model of counterproductive work behavior (CWB). Ed. S. Fox \& P. E. Spector, Counterproductive work behavior: Investigations of actors and targets. Washington DC: American Psychological Association.

Tanoğlu S.C., Arıcıoğlu, M.A. \& Kocabaş, M. (2007). Research on mobbing in organizations: A case study on academicians. Proceedings of the 37th International Conference on Computers and Industrial Engineering, 558-568.

Tanrıverdi, H., Koçaslan, G. \& Osmanoğlu-Taştan, N. (2018). Psikolojik şiddet algısı, tükenmişlik sendromu ve işten ayrılma niyeti arasındaki ilişki: Banka çalışanları üzerinde bir araştırma. Manisa CBÜ İ̈BF Yönetim ve Ekonomi Dergisi, 25(1): 113-131.

Tengilimoglu D. \& Akdemir-Mansur, F. (2009). İşletmelerde uygulanan mobbing'in (psikolojik şiddet) örgütsel bağl1lığa etkisi. Uluslararası İktisadi ve İdari İncelemeler Dergisi, 1(3):6984.

Tetik, S. (2010). Mobbing kavramı: Birey ve örgütler açısından önemi. Karamanoğlu Mehmetbey Üniversitesi Sosyal ve Ekonomik Araştırmalar Dergisi, 12(18): 81-89

Tinaz, P. (2011). İşyerinde psikolojik taciz (Mobbing). İstanbul: Beta

Tınaz, P. (2006). İşyerinde psikolojik taciz (Mobbing). Çalışma ve Toplum Dergisi, 4: (13-28)

Tigrel E.Y. \& Kokalan, O. (2009). Academic mobbing in Turkey, International Journal of Behavioral, Cognitive, Educational and Psychological Sciences, 1(2):91-99. 
Turan, F. (2006) İşyerinde psikolojik yıldırma olgusu ve konuya ilişkin bir araştırma. Yayınlanmamış yüksek lisans tezi, İstanbul Üniversitesi Sosyal Bilimler Enstitüsü

TÜİK Haber Bülteni (2016). Küçük ve orta büyükteki girişim istatistikleri, Sayı: 21540, Yayınlanma tarihi: 25 Kasım 2016

Vartia, M. (1996). The sources of bullying- psychological work environment and organizational climate. European Journal of Work and Organizational Psychology, 5(2): 203-214.

Vartia, M. (2001). Consequences of workplace bullying with respect to the well-being of its targets and the observers of bullying. Scandinavian Journal of Work, Environment and Health, 27(1): 63-69. doi:10.5271/sjweh.588

Vickers, H.M. (2010). Introduction-Bullying, mobbing, and violence in public service workplaces: The shifting sands of "acceptable" violence. Administrative Theory \& Praxis, 32(1): 7-24.

Wright, T.A. \& Cropanzano, R. (1997) Well-being, satisfaction and job performance: Another look at the happy/productive worker thesis. in Academy of Management Best Papers Proceedings, Academy of Management, pp. 364-368.

Wright, T.A. \& Cropanzano, R. (2004). The role of psychological well-being in job performance: A fresh look at an age-old quest. Organizational Dynamics, 33(4): 338-351

Yildirım, A. \& Yildırım, D. (2007). Mobbing in the workplace by peers and managers: Mobbing experienced by nurses working in healthcare facilities in Turkey and its effect on nurses. Journal of Clinical Nursing, 16:1444-1453.

Yu, G.C. \& Park, J.S. (2006). The effect of downsizing on the financial performance and employee productivity of Korean firms. International Journal of Manpower, 27(3): 230-250.

Yuceturk, E.E. (2003). Bilgi çağında örgütlerin görünmeyen yüzü: Mobbing, 2. Ulusal Bilgi, Ekonomi ve Yönetim Kongresi Bildiriler Kitabı, 1-10.

Zapf, D. \& Einarsen, S. (2001). Bullying in the workplace: Recent trends in research and practice- an introduction. European Journal of Work and Organizational Psychology, 10(4): 369-373. doi:10.1080/13594320143000807

Zapf, D., Knorz, C. \& Kulla, M. (1996). On the relationship between mobbing factors, and job content, social work environment, and health outcomes. European Journal of Work and Organizational Psychology, 5(2): 215-237.

\section{SUMMARY}

The concept of mobbing has been a matter of debate since 1980s in the world and is being discussed for quite a short time in Turkey. Considering its destructive effects on people, organizations and society, mobbing is a concept that should be handled carefully.

The aim of this study is to reveal the relation between mobbing and employee productivity. A field study consisting of administrative staff of SMEs in Manisa Organized Industrial Zone, who are not holding any managerial duties, was conducted and unexpectedly, attacks to relations and jobs dimensions of mobbing showed significant and positive relations with employee productivity.

In the study, this result is considered with Turkey specific cultural socioeconomic settings. First, cultural norms may force people to normalize and accept -to a level while those come from the superiors- such mobbing behaviors. Secondly, it is hard to simply quit a job in Turkey when unemployment rate is this high and employment opportunities are very few. Therefore, this state of acceptance depending on cultural values and forcing economic structure are considered as the reasons people being tolerant to mobbing behaviors. Furthermore, the reason behind increased productivity may also explained on the same manner: people may make try harder to prove their contributions to their employers in order to stay at their positions and to overcome mobbing behaviors. 